\title{
IMPLEMENTASI PEMBELAJARAN INKLUSIF \\ DI SD PELITA BANGSA GLOBAL ISLAMIC SCHOOL (GIS) TANGERANG SELATAN
}

\author{
Itsam Samrotul Fuadah \\ Esi Hairani \\ Institut Ilmu Al-Qur'an Jakarta \\ itsam90@gmail.com \\ esihairani@iiq.ac.id
}

\begin{abstract}
In this study the researchers attempted to investigate, find, describe, and explain how SD Pelita Bangsa Global Islamic School (GIS) implements inclusive education learning properly so that the school's existence is still good until now, even more than 2 prospective students with special needs per year who list and want to go to school at the school and the majority of all students with special needs are complete until grade 6. The research uses descriptive research with the data analysis technique model of Miles and Huberman, namely the analysis consists of three flow activities that occur simultaneously, namely: data reduction, data presentation, withdrawal. The results of this study indicate that SD Pelita Bangsa GIS has attempted to plan lessons, especially in Arabic language subjects that are appropriate for students with special needs as described in the General Guidelines for the Implementation of Inclusive Education by the Directorate of PPK-LK Basic Education, Ministry of Education and Culture in 2014 Then, the implementation of inclusive learning, especially in Arabic subjects at SD Pelita Bangsa GIS, has been done well. And lastly, SD Pelita Bangsa GIS has carried out relevant assessments and reports of what schools implementing inclusive programs should do.
\end{abstract}

Keyword: Inclusive Learning, Arabic Learning.

\begin{abstract}
Abstrak
Pada penelitian ini peneliti berusaha untuk menyelidiki, menemukan, menggambarkan, dan menjelaskan bagaimana SD Pelita Bangsa Global Islamic School (GIS) mengimplementasikan pembelajaran pendidikan inklusif secara baik sehingga eksistensi sekolah tersebut masih baik hingga saat ini, bahkan lebih dari 2 calon siswa berkebutuhan khusus pertahunnya yang daftar dan ingin bersekolah di sekolah tersebut dan mayoritas semua siswa berkebutuhan khusus tuntas hingga kelas 6. Penelitian menggunakan penelitian dekriptif dengan model teknik analisis data Miles and Huberman yaitu analisis terdiri dari tiga alur kegiatan yang terjadi secara bersamaan yaitu: reduksi data, penyajian data, penarikan. Hasil dari penelitian ini bahwa SD Pelita Bangsa GIS telah berupaya melakukan perencanaan pembelajaran khususnya pada mata pelajaran Bahasa Arab yang tepat bagi siswa berkebutuhan khusus sebagaimana yang dijelaskan pada buku Pedoman Umum Penyelenggaraan Pendidikan inklusif oleh direktorat PPK-LK Pendidikan Dasar Kementerian Pendidikan dan Kebudayaan tahun 2014. Kemudian, Pelaksanaan pembelajaran inklusif khususnya pada mata pelajaran Bahasa Arab di SD Pelita Bangsa GIS telah dilakukan dengan baik. Dan terakhir, SD Pelita Bangsa GIS telah melakukan penilaian dan pelaporan yang relevan dengan apa yang seharusnya dilakukan oleh sekolah penyelenggara program inklusif.
\end{abstract}

Kata kunci: Pembelajaran Inklusif, Pembelajaran Bahasa Arab.

91 | Itsam Samrotul F. dan Esi Hairani: Implementasi Pembelajaran Insklusif,... 


\section{A. PENDAhuluan}

Pendidikan merupakan hak yang dimiliki setiap warga Negara Indonesia, termasuk mereka yang berkebutuhan khusus. Dalam Undang-Undang Nomor 20 Tahun 2003 pada Pasal 5 Ayat 1 dinyatakan bahwa setiap warga negara mempunyai hak yang sama untuk memperoleh pendidikan yang bermutu. Peran pemerintah dalam melakukan pemerataan penyelenggaraan pendidikan tentu sangat berpengaruh dan penting dalam pengembangan pendidikan.

Selama ini yang menjadi hal lumrah di masyarakat adalah bahwa pendidikan bagi anak berkebutuhan khusus lebih banyak diselenggarakan secara segrasi di Sekolah Luar Biasa (SLB) dan Sekolah Dasar Luar Biasa (SDLB). Sementara itu, lokasi SLB dan SDLB pada umumnya berada di Ibu Kota Kabupaten, padahal anakanak berkebutuhan khusus banyak tersebar hampir di seluruh daerah (Kecamatan/Desa). Selain itu juga, Sekolah Luar Biasa (SLB) masih menjadi pemisah bagi anak-anak berkebutuhan khusus dengan anak-anak reguler pada umumnya, hal ini menghambat proses interaksi di antara mereka. Akibatnya anak berkebutuhan khusus menjadi kelompok yang terdiskriminasi dalam interaksi sosialnya di masyarakat. Masyarakat menjadi tidak akrab dengan anak berkebutuhan khusus, dan begitupun sebaliknya, anak berkebutuhan khusus merasa bukan bagian dari kehidupan masyarakat disekitarnya.

Dalam Islam, pendidikan juga tidak diwajibkan dengan membedakan manusia. Kewajiban menuntut ilmu tidak terbatas hanya untuk sebagian golongan saja namun juga wajib bagi seluruh muslim laki-laki dan perempuan baik normal atau dengan keterbatasan. Banyak sumber Islam baik dalam Al-Qur`an maupun Hadist menjelaskan keutamaan menuntut ilmu sehingga dapat kita ketahui bagaimana pentingnya menuntut ilmu bagi manusia. Karena ilmu adalah kebutuhan seorang muslim dalam menjalankan peran dan fungsinya di dunia sebagai makhluk Allah swt. Kewajiban tersebut dapat kita amati dalam Q.S al-Alaq ayat 1-5:

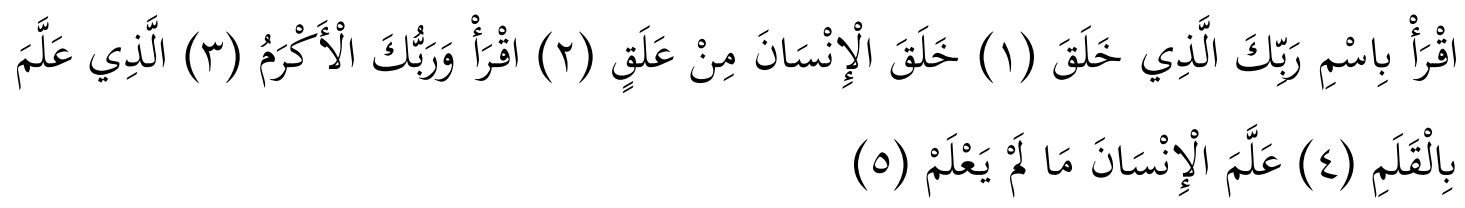

"Bacalah dengan (menyebut) nama Tuhanmu yang menciptakan, Dia telah menciptakan manusia dari 'Alaq, Bacalah, dan Tuhanmulah yang paling Pemurah, Yang mengajar manusia dengan pena, Dia mengajarkan kepada manusia apa yang belum diketahuinya." (Q.S al-Alaq [96]:1-5)

Dalam Q.S al-Alaq ayat 1-5 diatas dijelaskan bagaimana manusia diperintahkan untuk belajar secara terus menerus hingga akhir hayatnya untuk membangun peradaban. Maka pendidikan inklusif adalah salah satu solusi untuk manusia yang memiliki keterbatasan (berkebutuhan khusus) agar dapat menuntut ilmu dan mendapatkan pembelajaran seperti manusia lainnya. 
Salah satu kesepakatan internasional yang mendorong terwujudnya sistem pendidikan inklusif adalah Conventional on the Right of Person with Disabiliteis and optional Protocol yang disahkan pada Maret 2007. Yang mana pada pasal 24 dalam konvensi ini dijelaskan bahwa setiap Negara berkewajiban untuk menyelenggarakan sistem pendidikan inklusif di setiap tingkatan pendidikan. ${ }^{1}$ Kemudian dalam Surat Edaran Dirjen Dikdasmen Depdiknas No.380/C.C6/MN/2003 tanggal 20 Januari 2003 Perihal Pendidikan Inklusif diyatakan bahwa setiap Kabupaten/Kota sekurangkurangnya menyelenggarakan dan mengembangkan 4 (empat) sekolah.

Pemberlakuan Undang-Undang Nomor 20 Tahun 2003 tentang Sistem Pendidikan Nasional pasal 15 dan 32, Peraturan Pemerintah Nomor 19 Tahun 2005 tentang Standar Nasional Pendidikan, Undang-Undang No 8 Tahun 2016 tentang penyandang Disabilitas, Peraturan Pemerintah Republik Indonesia Nomor 13 Tahun 2020 tentang Akomodasi Yang Layak Untuk Peserta Didik Penyandang Disabilitas dan Peraturan Menteri Pendidikan Nasional Nomor 70 Tahun 2009 tentang Pendidikan Inlusif bagi Peserta didik yang Memiliki Kelainan dan Memiliki Potensi Kecerdasan dan/atau Bakat Istimewa serta UU Nomor 23 Tahun 2014 Tentang Pemerintah Daerah, membuat Pemerintah Kabupaten/Kota banyak yang proaktif untuk menyelenggarakan pendidikan inklusif.

Namun masih sangat banyak sekolah yang belum siap melakukan hal itu. Sehingga tujuan pendidikan inklusif sebagaimana tercantum dalam Permendiknas Nomor 70 Tahun 2009 pasal 2 tidak dapat tercapai. Dalam perkembangannya, beberapa sekolah mulai menerima anak berkebutuhan khusus belajar di lembaga pendidikannya, namun tidak sedikit anak-anak berkebutuhan khusus tersebut berhenti di tengah dan tidak berhasil menuntaskan pendidikan mereka. Hal tersebut menjadi salah satu hal yang berhasil menarik perhatian pihak Yayasan Pendidikan Pelita Bangsa Tangsel untuk membuka program inklusif bagi anak-anak berkebutuhan khusus.

Berdasarkan SK Kepala Dinas Pendidikan dan Kebudayaan Kota Tangerang Selatan Nomor 421/Kep.560-Bid.SD/2017 tentang Penetapan Nama-nama Sekolah Penyelenggara Sekolah Pendidikan Inklusif, bahwa terdapat 13 sekolah yang terdaftar sebagai sekolah yang menyelenggarakan konsep pendidikan inklusif, salah satunya adalah SD Pelita Bangsaa Global Islamic School (GIS) Pamulang Barat Tangsel. Berikut daftar nama-nama sekolah penyelenggara pendidikan inklusif Dinas Pendidikan dan Kebudayaan Kota Tangerang Selatan tahun 2017:

1 N. Praptiningrum, "Fenomena Penyelenggaraan Pendidikan Inklusif Bagi Anak Berkebutuhan Khusus" dalam Jurnal Pendidikan Khusus Vol. 17 No. 2 Nopember 2010, 33 
Tabel 1.1 Daftar Nama-Nama Sekolah Penyelenggara Pendidikan Inklusif Dinas Pendidikan dan Kebudayaan Kota Tangerang Selatan Tahun $2017 .{ }^{2}$

\begin{tabular}{|c|c|c|}
\hline NO & NAMA SEKOLAH & ALAMAT SEKOLAH \\
\hline 1. & SD Negeri Muncul 01 & $\begin{array}{l}\text { J1. Raya Puspiptek Kelurahan } \\
\text { Muncul Kec. Setu }\end{array}$ \\
\hline 2. & SD Negeri Babakan 01 & $\begin{array}{l}\text { J1. Pasar Jengkol Desa Babakan } \\
\text { Kec. Setu }\end{array}$ \\
\hline 3. & $\begin{array}{l}\text { SD Negeri Pondok } \\
\text { Jagung } 03\end{array}$ & $\begin{array}{l}\text { Asrama Yon Kav 9/BU RT 03/03 } \\
\text { Pondok Jagung }\end{array}$ \\
\hline 4. & SD Negeri Serpong 04 & Jl. Cendana III No. 43 \\
\hline 5. & SD Islam Amalina & Jl. Raya Pondok Aren No. 8 \\
\hline 6. & $\begin{array}{l}\text { SD Islam Plus Baitul } \\
\text { Maal }\end{array}$ & $\begin{array}{l}\text { Jl. Ceger Raya No. } 55 \text { Kec. Pondok } \\
\text { Aren }\end{array}$ \\
\hline 7. & $\begin{array}{l}\text { SD Islam Terpadu } \\
\text { Matahari }\end{array}$ & J1. Jurang Mangu Barat RT 02/02 \\
\hline 8. & SD Pelita Bangsaa - GIS & $\begin{array}{l}\text { Jl. Surya Kencana, Gg. Ketapang I } \\
\text { No. } 23 \text { Pamulang Barat Barang, } \\
\text { Tangsel }\end{array}$ \\
\hline 9. & SD Alam Bintaro & $\begin{array}{l}\text { J1. Pondok Pucung Raya RT 01/01 } \\
\text { No. } 88\end{array}$ \\
\hline 10. & $\begin{array}{l}\text { SD Islam Terpadu } \\
\text { Al-Fath Cireundeu }\end{array}$ & Jl. Cirendeu Raya No. 24 \\
\hline 11. & SD Islam al-Azhar BSD & $\begin{array}{l}\text { J1. Puspita Loka Sektor } 3.2 \text { BSD } \\
\text { City }\end{array}$ \\
\hline 12. & $\begin{array}{l}\text { SD IslamTerpadu } \\
\text { Cordova }\end{array}$ & $\begin{array}{l}\text { J1. Jaros Raya No. } 9 \text { Pondok Jati, } \\
\text { Jurang Mangu Barat }\end{array}$ \\
\hline 13. & $\begin{array}{l}\text { SMP Islam Plus Daarus } \\
\text { Salam }\end{array}$ & $\begin{array}{l}\text { J1. Pesantren RT 003/01 No. 62B } \\
\text { Pondok Aren }\end{array}$ \\
\hline
\end{tabular}

SD Pelita Bangsaa Global Islamic School (GIS) merupakan sekolah swasta penyelenggara program inklusif yang telah terakreditasi. Berdasarkan informasi awal yang peneliti dapatkan pada saat melakukan wawancara dengan Kepala Sekolah ketika tugas kuliah Seminar Proposal dan dilanjutkan dengan kegiatan PLP 2 diketahui bahwa SD Pelita Bangsaa Global Islamic School (GIS) sudah terakreditasi sangat baik (A). Peneliti tertarik untuk mengetahui lebih jauh apakah sekolah ini memiliki pembelajaran termasuk di dalamnya perencanaan, pelaksanaan dan penilaian yang sudah sesuai dengan aturan dan pedoman serta bagaimana sekolah ini mengimplementasikannya dalam keseharian. Sekolah ini berada di Kecamatan Pamulang Barat Barat, Kota Tangerang Selatan, Provinsi Banten.

\footnotetext{
2 Berdasarkan SK Kepala Dinas Pendidikan dan Kebudayaan Kota Tangerang Selatan Nomor: 421/Kep.560-Bid.SD/2017
} 
Berkaitan dengan latar belakang di atas serta ketertarikan peneliti dengan praktik dari materi yang disampaikan ketika mendapatkan mata kuliah Inklusi, maka peneliti tertarik untuk melakukan penelitian tentang "Implementasi Pembelajaran Inklusif di SD Pelita Bangsaa Global Islamic School (GIS), Tangerang Selatan”.

\section{B. METODE PENELITIAN}

\section{Jenis Penelitian dan Pendekatan}

Jenis penelitian yang digunakan adalah penelitian kualitatif (qualitative research), yaitu penelitian untuk menjawab permasalahan yang memerlukan pemahaman secara mendalam dalam konteks waktu dan situasi yang bersangkutan, dilakukan secara wajar dan alami sesuai dengan kondisi objektif di lapangan tanpa adanya manipulasi, serta jenis data yang dikumpulkan terutama data kualitatif. ${ }^{3}$ Pada penelitian ini peneliti berusaha untuk menyelidiki, menemukan, menggambarkan, dan menjelaskan bagaimana SD Pelita Bangsa Global Islamic School (GIS) mengimplementasikan pembelajaran pendidikan inklusif secara baik sehingga eksistensi sekolah tersebut masih baik hingga saat ini, bahkan lebih dari 2 calon siswa berkebutuhan khusus pertahunnya yang daftar dan ingin bersekolah di sekolah tersebut dan mayoritas semua siswa berkebutuhan khusus tuntas hingga kelas 6 .

Penelitian ini menggunakan pendekatan deskriptif, artinya peneliti menyelidiki, memahami, serta memusatkan diri secara intensif terhadap implementasi pembelajaran pendidikan inklusif di SD Pelita Bangsa GIS dengan mengumpulkan berbagai macam informasi yang dilakukan secara integrative dan komperhensif. Penelitian deskriptif mempelajari masalah-masalah masyarakat, serta tata cara yang berlaku dalam masyarakat serta situasi-situasi tertentu, termasuk tentang hubungan, kegiatan-kegiatan, sikap-sikap, pandangan-pandangan, serta proses yang sedang berlangsung dan pengaruh-pengaruh suatu fenomena. ${ }^{4}$ Abdurrahmat Fatohi mengemukakan penelitian deskriptif yaitu suatu penelitian yang bermaksud mengadakan pemeriksaan dan mengadakan pengukuranpengukuran terhadap gejala tertentu. ${ }^{5}$ Sumadi Suryabrata juga berpendapat penelitian deskriptif adalah penelitian yang bermaksud untuk membuat pencandraan (deskriptif) mengenai situasi-situasi atau kejadian-kejadian. ${ }^{6}$ Data diperoleh dari semua pihak yang bersangkutan, yang kemudian diolah untuk mendapatkan sebuah solusi agar masalah yang diungkap dapat terselesaikan.

\section{Teknis Analisis Data}

Penelitian kualitatif menggunakan analisis data secara induktif dengan model Miles and Huberman. Analisis induktif digunakan karena lebih dapat menemukan kenyataan-kenyataan ganda yang terdapat dalam data, selain itu, analisis induktif lebih dapat membuat hubungan peneliti-responden menjadi eksplisit, dapat dikenal, dan akauntable. Analisis induktif juga dapat menguraikan latar secara penuh. Adapun

${ }^{3}$ Drs. Zainal Arifin, M.Pd, Penelitian Pendidikan : Metode dan Paradigma Baru, (Bandung: PT Remaja Rosdakaya, 2014), hlm.29

${ }^{4}$ Moh. Nazir, Ph. D, Metode Penelitian... hlm. 55

5 Abdurahman Fathoni, Metodologi Penelitian dan Teknik Pengumpulan Data, (Jakarta:Rineka Cipta, 2006), hlm.97

${ }^{6}$ Suryabrata Sumadi, Metodologi Penelitian, (Jakarta : PT Raja Grafindo Persada, 2000 ), hlm.18 
analisis data diperoleh dari hasil wawancara, catatan lapangan, dan dokumentasi, dengan cara mengorganisasikan data ke dalam kategori, menjabarkan ke dalam unitunit, melakukan sintesa, menyusun ke dalam pola, memilih mana yang penting dan yang akan dipelajari, dan membuat kesimpulan sehingga mudah dipahami oleh diri sendiri maupun orang lain. ${ }^{7}$ Analisis data dalam penelitian kualitatif, dilakukan pada saat pengumpulan data berlangsung, dan setelah selesai pengumpulan data dalam periode tertentu. Adapun aktivitas dalam analisis data dalam penelitian ini yaitu reduksi data, penyajian data, dan verifikasi atau kesimpulan. ${ }^{8}$

\section{ANALISIS DAN TEMUAN}

Pelaksanaan pembelajaran inklusif khususnya pada mata pelajaran Bahasa Arab di SD Pelita Bangsa GIS telah dilakukan dengan baik. Sekolah juga telah memberikan pembelajaran dengan kompetensi-kompetensi fungsional (skill) yang dibutuhkan untuk kemandirian dalam aktivitas kehidupan serta pembiasaanpembiasaan spiritual untuk menumbuhkan sikap (akhlak), spiritualitas keagamaan serta perkembangan otak dan karakter siswa berkebutuhan khusus. Analisis data pada penelitian ini dapat digambarkan pada aspek:

\section{Sistem Penilaian dan Pelaporan}

Penilaian hasil belajar pada Kurikulum 2013 ini dilakukan oleh pendidik dan satuan pendidik melalui tahapan mengkaji silabus sebagai acuan perencanaan penilaian, pembuatan kisi-kisi instrumen dan penetapan kriteria penilaian, pelaksanaan penilaian dalam proses pembelajaran, menganalisis hasil penilaian dan memberi tindak lanjut atas penilaian yang dilakukan oleh pendidik, menyusun laporan hasil penilaian dalam bentuk deskripsi pencapaian kompetensi dan deskripsi sikap.

Penilaian untuk siswa program inklusif berbeda dengan siswa reguler. SD Pelita Bangsa GIS memiliki instrumen penilaian khusus yang dibuat secara ekskulif oleh Dokter sekaligus Pembina program inklusif di Yayasan Pelita Bangsa. Penilaian menggunakan instrumen itu dilakukan untuk mengetahui perkembangan siswa berkebutuhan khusus dengan menilai lima (5) aspek perkembangan yang berbeda. Kelima aspek tersebut adalah:

a. Bina Kognisi Dasar meliputi: sistem keseimbangan, motorik kasar, motorik halus, daya tangkap, daya balas, bahasa, prilaku dan sikap serta mandiri sosial.

b. Bina Didik (bimbingan belajar) meliputi: Perkembangan calistung dan perkembangan hasil belajar.

c. Bina Sosial (bimbingan sosial) meliputi: kooperatif terhadap peraturan, pengendalian emosi, kemandirian dan tanggung jawab.

d. Bina Diri (bimbingan keterampilan) meliputi: merapikan alat dan buku tulis, memakai dan melepas sepatu, membuka dan menutup botol, merapikan peralatan makan, serta memakai dan melepas baju.

\footnotetext{
${ }^{7}$ Sugiyono, Metode Penelitian Pendidikan, hal. 335

${ }^{8}$ Sugiyono, Metode Penelitian Pendidikan, hal. 337
} 
e. Bina Sehat (bimbingan kesehatan) meliputi: kesehatan penglihatan, kesehatan pendengaran dan gizi. ${ }^{9}$

Tabel 4.8 Contoh Instrumen Penilaian Perkembangan Siswa Berkebutuhan Khusus ${ }^{10}$.

\section{A. SISTEM KESEIMBANGAN}

\begin{tabular}{|l|l|c|c|c|c|}
\hline a. & Reaksi Bobot Badan & 1 & 3 & 6 \\
\hline & Angkat satu kaki dengan mtutup mata & 1 & 3 & 6 & 9 \\
\hline & Melompat mundur dengan satu kaki diangkat & 1 & 3 & 6 & 9 \\
\hline & Berjalan mundur diatas garus atau balok titian & 1 & 3 & 6 & 9 \\
\hline & Berjalan mundur menaiki tangga & & & \\
\hline b. & Reaksi Koordinasi Tubuh & 3 & 6 & 9 \\
\hline & Telentang mata tertutup mempertemukan kedua jempol kaki & & 3 \\
\hline & $\begin{array}{l}\text { Telungkup di meja, kaki bergantungan mempertemukan kedua jempol } \\
\text { kaki }\end{array}$ & 1 & 6 & 9 \\
\hline & Mempertemukan ujung jari kedua tangan di belakang & 1 & 3 & 6 & 9 \\
\hline & Melompat-lompat ke depan di atas dua keset yang dipindahkannya & 1 & 3 & 6 & 9 \\
\hline & B. MOTORIK KASAR & &
\end{tabular}

\begin{tabular}{|c|c|c|c|c|c|}
\hline \multirow[t]{2}{*}{ a. } & \multicolumn{5}{|l|}{ Sikap Tubuh } \\
\hline & Melempar dan menangkat bola & 1 & 3 & 6 & 9 \\
\hline & Menggerakan anggota badan menyilang & 1 & 3 & 6 & 9 \\
\hline b. & \multicolumn{5}{|l|}{ Tonus } \\
\hline & Tidur telentang mengangkat-angkat perut & 1 & 3 & 6 & 9 \\
\hline c. & \multicolumn{5}{|l|}{ Rancang Motorik } \\
\hline & Melakukan gerakan yang tidak dikenal sebelumnya & 1 & 3 & 6 & 9 \\
\hline d. & \multicolumn{5}{|l|}{ Orientasi Diri } \\
\hline & Menutup mata kanan kemudian kiri & 1 & 3 & 6 & 9 \\
\hline & Mengangkat kaki kanan kemudian kiri & 1 & 3 & 6 & 9 \\
\hline & Mengangkat tangan kanan kemudian kiri & 1 & 3 & 6 & 9 \\
\hline \multicolumn{6}{|c|}{ C. MOTORIK HALUS } \\
\hline a. & \multicolumn{5}{|l|}{ Koordinasi Mata dan Telinga } \\
\hline & Menggunting kertas sesuai gambar & 1 & 3 & 6 & 9 \\
\hline & Meronce manik-manik & 1 & 3 & 6 & 9 \\
\hline
\end{tabular}

${ }^{9}$ Dr BGS, Pembina Program inklusif di Yayasan Pelita Bangsa, wawacara terstruktur pada hari Rabu, 29 Juni 2020 pukul 20.20 WIB WIB melalui WhatsApp Call

${ }^{10}$ Instrumen lengkapnya lihat di lampiran

97 | Itsam Samrotul F. dan Esi Hairani: Implementasi Pembelajaran Insklusif,... 


\begin{tabular}{|c|c|c|c|c|c|}
\hline & Memutar benda dengan jari-jari satu tangan & 1 & 3 & 6 & 9 \\
\hline \multirow[t]{3}{*}{ b. } & \multicolumn{5}{|l|}{ Graphmotor } \\
\hline & Menggunakan pensil menggambar persegi empat, segitiga, lingkaran & 1 & 3 & 6 & 9 \\
\hline & Menghapus gambar mulai persegi empat, segitiga kemudian lingkaran & 1 & 3 & 6 & 9 \\
\hline \multirow[t]{2}{*}{ c. } & \multicolumn{5}{|l|}{ Visualmotor } \\
\hline & Mengikuti dengan mata gerakan pensil & 1 & 3 & 6 & 9 \\
\hline \multirow[t]{2}{*}{ d. } & \multicolumn{5}{|l|}{ Verbalmotor } \\
\hline & Menggoyang rahang, menjulurkan lidah & 1 & 3 & 6 & 9 \\
\hline
\end{tabular}

Selain penilaian seperti diuraikan di atas, penilaian lain juga diakumulasikan dengan hasil laporan kegiatan dan perkembangan harian siswa yang ditulis oleh Guru inklusif (shadow teacher).Khusus untuk penilaian pembelajaran siswa berkebutuhan khusus, Kriteria Ketuntasan Minimum (KKM) yang digunakan tidak disamakan dengan siswa reguler. Kegiatan ini dilakukan secara berkala dan selalu rutin dibahas dalam pertemuan khusus guru pendamping khusus (shadow teacher) dengan kepala sekolah dan tenaga professional. Laporan perkembangan siswa berkebutuhan khusus dilakukan tiga bulan sekali.

Dalam penentuan Kriteria Ketuntasan Minimum (KKM) Ms MM menuturkan bahwa,

Guru-guru akan melihat terlebih dulu anak berkebutuhan khusus secara individu, apakah dia bisa mengikuti pembelajarn reguler atau tidak. Jika siswa tersebut mampu mengikuti pembelajaran reguler maka KKM nya disamakan dengan anak reguler, tetapi tetapi jika siswa tersbut tidak mampu mengikuti maka kita berikan KKM dibawah reguler misalnya 50 atau 60 seperti itu. ${ }^{11}$

Berikut adalah contoh tabel hasil belajar yang ada pada laporan hasil belajar siswa berkebutuhan khusus di SD Pelita Bangsa GIS

Tabel 4.9 Contoh Leger KI.3 Laporan Hasil Belajar Mata Pelajaran Bahasa Arab Siswa Berkebutuhan Khusus kelas 4

\begin{tabular}{|l|l|l|c|c|c|c|c|}
\hline \multirow{2}{*}{ No } & \multirow{2}{*}{ Nama Lengkap } & Pelajaran & KKM & Nilai & \multicolumn{3}{|c|}{ Predikat } \\
\cline { 5 - 7 } 1 & STH & $\begin{array}{c}\text { Bahasa } \\
\text { Arab }\end{array}$ & 65 & 75 & B & Baik & Alhamdulillah \\
\hline
\end{tabular}

11 Ms MM, Guru Pendamping Khusus (GPK)/Guru inklusif Kelas 1 SD Pelita Bangsa GIS, wawacara terstruktur pada hari Selasa, 14 April 2020 pukul 08.53 WIB WIB melalui WhatsApp Voice Not 


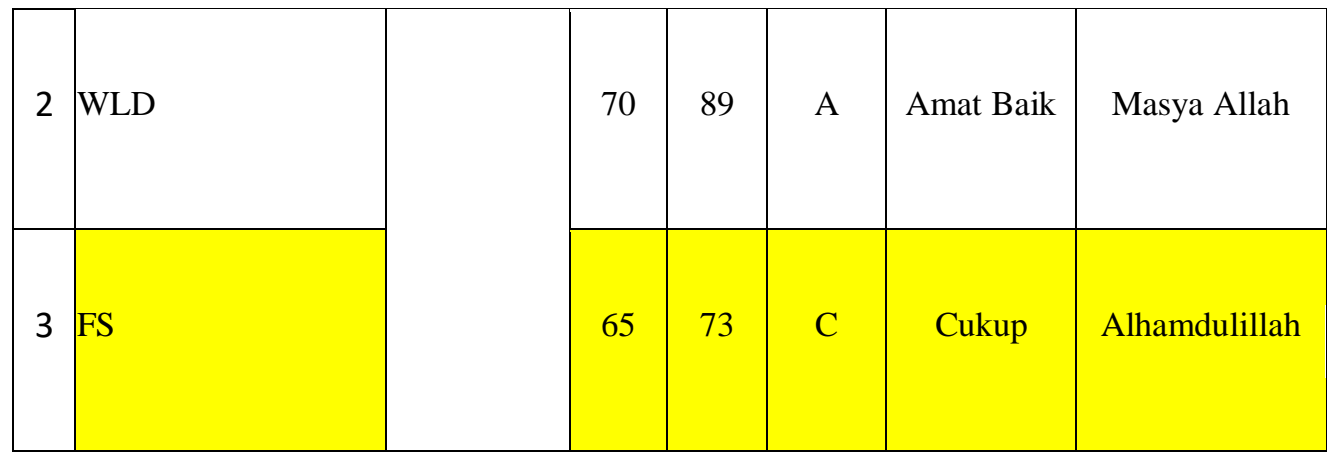

Dari tabel tersebut dapat diketahui bahwa KKM yang ditentukan untuk siswa berkebutuhan khusus berbeda dengan siswa reguler. Siswa berkebutuhan khusus tidak dipaksa untuk dapat memiliki dan mencapai nilai yang tinggi seperti yang ditargetkan pada siswa berkebutuhan khusus. Modifikasi atau penyesuaian penilaian seperti itu membuat hasil penilaian yang cukup representatif terhadap hasil belajar siswa berkebutuhan khusus sebagaimana adanya. Nilai akhir yang ditulis pada laporan hasil belajar adalah akumulasi dari keseluruhan nilai proses hingga penilaian akhir yaitu dengan rincian $20 \%$ nilai rata-rata tugas, $30 \%$ rata-rata nilai Penilaian Harian (UH/PH), 20\% nilai hasil PTS (Penilaian Tengah Semester) dan $40 \%$ nilai PAT (Penilaian Akhir Semester). ${ }^{12}$ Tabel diatas juga memberikan informasi bahwa kedua siswa berkebutuhan khusus di kelas 4 telah tuntas mengikuti pembelajaran dengan nilai diatas KKM siswa berkebutuhasn khusus. Keduanya mendapatkan akumulasi nilai yang cukup dan baik sehingga menunjukan bahwa siswa berkebutuhan khusus tersebut telah mampu mengikuti pembelajaran sesuai dengan kemampuannya masing-masing.

Berdasarkan penilaian-penilaian seperti yang dijelaskan di atas, pihak sekolah dapat melalukan inovasi pembelajaran kedepannya agar siswa yang bersangkutan dapat mengalami perkembangan yang lebih baik.

Adapun sistem pelaporan yang dilakukan oleh SD Pelita Bangsa GIS adalah berdasarkan penilaian yang dilakukan setiap sebulan sekali dalam bentuk observasi. Hasil penilaian tersebut kemudian akan dibuatkan laporan berbentuk grafik dan dinarasikan sesuai dengan perkembangan yang terjadi dalam tiga bulan terakhir. Berikut adalah contoh grafik penilaian hasil belajar dan perkembangan siswa berkebutuhan khusus per tiga bulan sekali yang kemudian akan dijadikan laporan pembelajaran dan perkembangan di SD Pelita Bangsa GIS:

Grafik 4.1 contoh grafik penilaian hasil belajar dan perkembangan siswa berkebutuhan khusus per tiga bulan sekali di SD Pelita Bangsa GIS

\footnotetext{
${ }^{12}$ Berdasarkan file format penilaian untuk Guru Mata Pelajaran (bidang studi) SD Pelita Bangsa GIS, Tangerang Selatan
} 


\section{Grafik Perkembangan Sistem Keseimbangan}

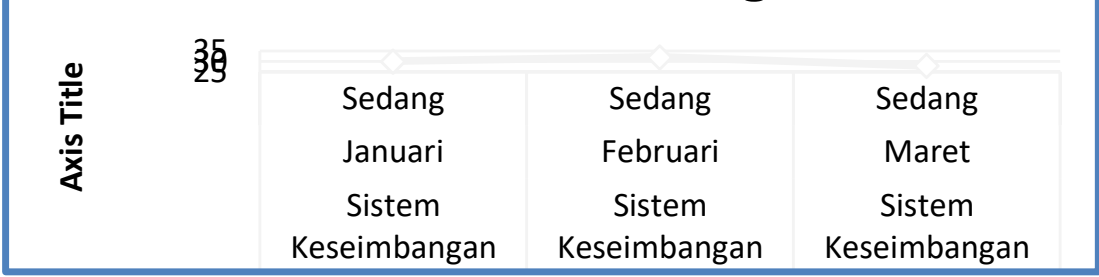

Adapun menindaklanjuti pembelajaran daring, sekolah telah berupaya untuk memodifikasi sistem penilaian dan pelaporan. hal tersebut dilakukan karena kondisi pembelajaran yang dilakukan di rumah sehingga menjadi kendala bagi guru inklusif untuk dapat mendeskripsinya bagaimana perkembangan siswa berkebutuhan khusus secara rinci. Oleh karena itu, selain penilaian hasil belajar, sekolah juga menyiapkan sistem penilaian dan pelaporan perkembangan siswa berkebutuhan khusus dengan terfokus pada 8 aspek perkembangan.

Adapun dalam pelaporan hasil belajar siswa berkebutuhan khusus, Ms TE menuturkan bahwa,

Sekolah tetap memakai raport seperti anak reguler. Kalau untuk laporan hasil belajar kita tetap memakai raport seperti anak reguler. Kalau untuk anak inklusif, ada laporan lain selain laporan hasil belajar. Yaitu laporan perkembangan kemandirian, emosional, motoric kasar, motoric halus dan lain-lain. Dan itu akan dicatat ole GPK selama setiap hari. Perkembangannya itu dicatat. Nah ada juga penilaian yang dilakukan setiap sebulan sekali berbentuk observasi. Jadi GPK mengobservasi anak untuk loncat, bermain bola, mewarnai, menggunting dan lain-lain. Dan dalam tiga bulan observasi itu akan digabungkan menjadi sebuah bagan. ${ }^{13}$

Dari paparan diatas, dapat dianalisis bahwa proses penilaian terhadap perkembangan siswa berkebutuhan khusus di SD Pelita Bangsa GIS dilaksanakan setiap hari (catatan pribadi tentang perkembangan siswa berkebutuhan khusus). Penilaian tersebut akan diakumulasikan dengan penilaian perkembangan setiap hari dilakukan sebulan sekali serta memberikan siswa berkebutuhan khusus 2 bentuk laporan yaitu laporan hasil belajar dan laporan perkembanganyang dilakukan per 3 bulan

Berdasarkan hasil analisis diatas, dapat disimpulkan bahwa SD Pelita Bangsa GIS telah melakukan penilaian dan pelaporan yang relevan dengan apa yang seharusnya dilakukan oleh sekolah penyelenggara program inklusif. Penilaian hasil belajar siswa berkebutuhandalam mata pelajaran Bahasa Arab dilakukan melalui penyesuaian terhadap KKM yang telah ditentukan. Hal unik yang dimiliki sekolah ini adalah memiliki instrumen peniliaian yang berbeda dengan sekolah pada umumnya dan disusun khusus oleh tim inklusif sekolah.

${ }^{13}$ Ms TE, Wali Kelas di SD Pelita Bangsa GIS, wawancara terstruktur pada hari Rabu, 29 April 2020 pukul 20.20 WIB melalui WhatsApp Voice Not

100 | Itsam Samrotul F. dan Esi Hairani: Implementasi Pembelajaran Insklusif,... 
Sama halnya dengan pembelajaran untuk pendidikan reguler, ada beberapa hal yang perlu dipahami dalam pembelajaran pendidikan inklusif yang dilaksanakan pada sekolah penyelenggara program inklusif yaitu desain perencanaan pembelajaran, pelaksanaan pembelajaran hingga penilaian dan pelaporan hasil pembelajaran.

1. Perencanaan Pembelajaran Pendidikan inklusif

Pada tahap ini dilakukan perencanaan pembelajaran dan penyusunan program khusus dengan menganalisis kurikulum nasional untuk dimodifikasi sesuai dengan kebutuhan siswa berkebutuhan khusus. Perencanaan pembelajaran dilakukan berdasarkan dari hasil analisis, identifikasi dan assesment seluruh calon siswa baru di sekolah tersebut. Setelah kemudian ditentukan siapa saja calon siswa yang ternyata memiliki kekhususan, maka disusunlan perencanaan pembelajaran tersebut.

Pendidikan inklusif yang telah diselenggarakan oleh SD Pelita Bangsa GIS ini telah berlangsung selama 11 tahun. Hal tersebut tidak menutup kemungkinan bahwa sekolah telah melakukan banyak perkembangan atau perbaikan terkait pelaksanaan pendidikan inklusif tersebut, baik dari segi pelayanan maupun pembelajaran.

Ms TE menjelaskan bahwa,

Karena kita sekolah swasta, jadi kurikulumnya kita bisa modifikasikan dan kita bisa kembangkan. Nah, untuk inklusif ini sudah kita kembangkan. Biasanya kurikulum pendidikan inklusif itu dikembangkan oleh tim. Nah timnya itu terdiri dari Guru, GPK (Guru Pendamping Khusus), Dokter, Kepsek dan pihak Yayasan. Nah, ketika kita mengembangkan suatu kurikulum itu kita merancang program kedepan untuk anak inklusif.gitu seperti program keagamaannya seperti apa, keterampilan, dan program treatmentnya seperti apa.

Perancangan desain kurikulum yang dilakukanoleh tim adalah bentuk awal perencanaan program kegiatan pembelajaran siswa di SD Pelita Bangsa GIS. Pada dasarnya, proses pembelajaran pendidikan inklusif ini tidak akan terlepas dari kurikulum. Kurikulum ini akan dijadikan sebagai pedoman pelaksanaan program pembelajaran dari mulai perencanaan hingga penilaian atau evaluasi dan pelaporan.

Berikut adalah contoh tabel pemetaan siswa sebagai bentuk kurikulum yang disesuaikan dengan kondisi masing-masing siswa berkebutuhan khusus di SD Pelita Bangsa-GIS

Tabel 4.5 Pemetaan Siswa Sebagai Bentuk Penyesuaian Kurikulum (Sesuaikan) di Kelas 4

\begin{tabular}{|l|l|l|c|c|}
\hline NO & NAMA & KELAS & $\begin{array}{c}\text { BENTUK } \\
\text { KURIKULUM }\end{array}$ & PEMBELAJARAN \\
\hline 1. & FS & Kelas 4 & Reguler dengan & $\begin{array}{c}\text { 1. Pembelajaran di kelas } \\
\text { dengan Guru }\end{array}$ \\
\hline
\end{tabular}

101 | Itsam Samrotul F. dan Esi Hairani: Implementasi Pembelajaran Insklusif,... 


\begin{tabular}{|c|c|c|c|c|}
\hline & & & Modifikasi & $\begin{array}{l}\text { Pendamping } \\
\text { 2. Modifikasi bahan ajar } \\
\text { 3. Program penunjnag } \\
\text { akademik: Brain gym, } \\
\text { bina diri dan live skill. }\end{array}$ \\
\hline 2. & STH & Kelas 4 & $\begin{array}{l}\text { Reguler dengan } \\
\text { Modifikasi }\end{array}$ & $\begin{array}{l}\text { 1. Pembelajaran di kelas } \\
\text { dengan Guru } \\
\text { Pendamping. Jika suatu } \\
\text { data dibutuhkan } \\
\text { pendampingan atau } \\
\text { pendalaman materi akan } \\
\text { diberikan sesuai } \\
\text { kebutuhan. } \\
\text { 4. Program penunjang } \\
\text { akademik: Terapi prilaku } \\
\text { dan brain gym. }\end{array}$ \\
\hline
\end{tabular}

Berdasarkan tabel pemetaan di atas, dapat diketahui bahwa sekolah telah menyiapkan rancangan pembelajaran untuk siswa berkebutuhan khusus di Kelas 4. Walaupun desain kurikulum untuk keduanya adalah reguler dengan modifikasi, namun desain pembelajaran yang dirancang dibuat berbeda. FS mendapatkan modifikasi bahan ajar sesuai dengan tingkat kemampuannya, namun STH tetap mendapatkan bahan ajar yang sama dengan pendampingan dari Guru Inklusif. Pemetaan seperti di atas dapat memudahkan guru inklusif membuat perencanaan pembelajaran ketika hendak melaksanakan pembelajaran.

Pada umumnya sekolah-sekolah inklusif menggunakan kurikulum yang sama dengan sekolah-sekolah reguler. Silabus dan RPP yang digunakan di sekolah inklusif juga pada umumnya sama. Artinya, sebagian besar guru-guru di sekolah inklusif hampir tidak membedakan RPP-nya namun dalam pelaksanaannya, bagi anak berkebutuhan khusus menerapkan standar yang lebih rendah dibandingkan dengan standar yang dikepada pesera didik lainnya. Kemudian yang dilakukan oleh pihak sekolah dalam hal ini adalah menyiapkan Guru inklusif yang telah diberi pelatihan secara berkala terkait penyelenggaraan dan pelaksanaan pembelajaran pendidikan inklusif sebagai pendamping khusus siswa berkebutuhan khusus. Orang tua tidak perlu lagi mencari dan membawa guru inklusif khusus ke sekolah dengan biaya yang besar. Guru inklusif yang telah disediakan oleh pihak sekolah akan membantu menyederhanakan (menyesuaikan) semua pembelajaran siswa berkebutuhan khusus yang bersangkutan agar tetap mengacu tujuan pembelajaran seperti siswa reguler lainnya. Hal ini selaras dengan apa yang disampaikan oleh Ms TE dan Ms MM dalam wawancara virtual. 
Terdapat beberapa hal yang menjadi perhatian dalam penyusunan perencanaan pembelajaran di sekolah inklusif. ${ }^{14}$ Ms TE dalam wawancara virtual menyampaikan bahwa,

Kalau untuk RPP kami tidak mencantumkan materi-materinya untuk anak berkebutuhan khusus, karena sebenarnya materinya sama, tapi hanya disesuaikan saja sama kemampuan. Disederhanaan. Tapi untuk materi, metode semuanya sama gitu. Jadi di RPP tidak kita cantumkan materi untuk anak inklusif. ${ }^{15}$

Pada prakteknya, ketika hendak melakukan pembelajaran, GPK atau Guru inklusif akan berkoordinasi dengan Wali Kelas maupun Guru bidang studi terkait materi yang akan dipelajari pada pembelajaran yang akan dilaksanakan. Guru inklusif tersebut akan menyederhanakan materi, menentukan media dan metode yang akan digunakan ketika membimbing siswa berkebutuhan khusus dalam pelaksanaan pembelajaran. Hal ini menunjukan bahwa sekolah telah menyiapkan alternatif lain sebagai solusi perencanaan pembelajaran untuk siswa berkebutuhan khusus.

Penjelasan Ms RY dan Ms TE diperkuat dengan adanya hasil obsevasi yang dilakukan oleh peneliti sejak pertama mengajar di sekolah tersbut, bahwa pembelajaran pendidikan inklusif untuk siswa berkebutuhan khusus dilaksanakan dengan penyesuaian kurikulum maupun program pembelajaran lainnya. Siswa berkebutuhan khusus dibimbing oleh Guru Pendamping Khusus (shadow teacher) dalam melakukan pembelajaran setiap harinya. Penyesuaian tersebut mencangkup pada penyeseuaian rencana, proses dan penilaian (evaluasi) pembelajaran, serta program-program pembelajaran khusus untuk anak berkebutuhan khusus sebagai penunjang dari kurikulum nasional yang telah dimodifikasi.

Berikut adalah tabel contoh penyesuaikan tujuan, materi, strategi/metode, langkah-langkah, sumber bahan, dan penilaian dalam mata pelajaran Bahasa Arab untuk siswa berkebutuhan khusus kelas 4 SD Pelita Bangsa GIS yang dirancang oleh guru inklusif (shadow teacher) kelas 4:

Tabel 4.6 Contoh Rancangan Pembelajaran Yang Dibuat Guru inklusif

\begin{tabular}{|c|l|}
\hline Materi & \multicolumn{1}{|c|}{ Nama-nama hari dalam bahasa Arab } \\
\hline \multirow{3}{*}{ Tujuan } & $\begin{array}{l}\text { 1. Siswa dapat mengucapkan nama-nama hari dalam bahasa } \\
\text { Arab dengan bimbingan shadow teacher } \\
\text { Arswa dapat menuliskan nama-nama hari dalam bahasa } \\
\text { Arab dengan atau tanpa bimbingan shadow teacher }\end{array}$ \\
& $\begin{array}{l}\text { 3. Siswa dapat menghafal minimal 2 nama hari dalam Bahasa } \\
\text { Arab }\end{array}$ \\
\hline Metode & Latihan dan bimbingan \\
\hline
\end{tabular}

\footnotetext{
${ }^{14}$ Pehatikan footnote no 72 pada BAB II

15 Ms TE, Wali Kelas di SD Pelita Bangsa GIS, wawancara terstruktur pada hari Rabu, 29 April 2020 pukul 20.20 WIB melalui WhatsApp Vice Not.
}

103 | Itsam Samrotul F. dan Esi Hairani: Implementasi Pembelajaran Insklusif,... 


\begin{tabular}{|c|c|}
\hline $\begin{array}{c}\text { Langkah- } \\
\text { langkah }\end{array}$ & $\begin{array}{l}\text { 1. Guru inklusif (shadow teacher) menulis nama-nama } \\
\text { bahasa Arab dengan spidol berwarna } \\
\text { 2. Guru inklusif membaca satu per satu kosa kata dan } \\
\text { meminta siswa berkebutuhan khusus untuk mengulang apa } \\
\text { yang diucapkan guru inklusif. } \\
\text { 3. Guru inklusif membimbing siswa berkebutuhan khusus } \\
\text { untuk menyalin tulisan kosa kata bahasa Arab tersebut } \\
\text { minimal } 3 \\
\text { 4. Guru inklusif membimbing siswa berkebutuhan khusus } \\
\text { untuk bisa mgucapkan dan menghafalkan kosa kata yang } \\
\text { ia tulis. }\end{array}$ \\
\hline $\begin{array}{l}\text { Sumber } \\
\text { Bahan }\end{array}$ & Buku Bahasa Arab seperti yang digunakan siswa reguler. \\
\hline Penilaian & $\begin{array}{l}\text { Penilaian apa adanya dengan KKM } 60 \text { dan } \\
\text { mempertimbangkan proses belajar siswa berkebutuhan } \\
\text { khusus. }\end{array}$ \\
\hline
\end{tabular}

Penyesuaian tersebut dilakukan agar tidak memberatkan siswa berkebutuhan khusus dan mampu memacu potensi siswa berkebutuhan khusus agar dapat mengembangkan dengan kemampuannya. Hal tersebut dibuat dengan pertimbangan kemampuan siswa yang bersangkutan dan koordinasi antara guru bidang studi atau guru kelas dengan guru inklusif terkait materi yang akan disampaikan dalam pelaksanaan pembelajaran. Akan tetapi, berdasarkan observasi dilapangan diketahui bahwa tidak semua guru inklusif dan juga tidak dalam semua pembelajaran perencaan secara tertulis seperti di atas dilakukan. Walaupun pada pelaksanaannya, pembelajaran tetap berjalan dengan baik dan terkendali.

Berdasarkan tabel di atas juga diketahui bahwa metode yang digunakan dalam pembelajaran inklusif di SD Pelita Bangsa GIS termasuk juga untuk mata pelajaran Bahasa Arab adalah dengan metode latihan dan bimbingan langsung dari Guru Inklusif fengan pendekatan individu. Artinya, kedua siswa berkebutuhan khusus dalam satu kelas akan mendapatkan bimbingan yang berbeda sesuai dengan individu masing-masing. Di kelas 4 dapat dideskripsikan bahwa pembelajaran bahasa Arab untuk siswa berkebutuhan khusus mendapatkan penyesuaian yang cenderung drastis, karena keduanya memliki banyak kesulitan dalam pelafalan maupun penulisan bahasa Arab. Oleh karena itu, tujuan pembelajaran yang ditargetkan untuk siswa berkebutuhan khusus di kelas 4 ini sebatas dapat meniru dan mengikuti baik dalam tulisan maupun dalam pelafalan. ${ }^{16}$

Berikut adalah gambar tugas belajar Bahasa Arab yang dikerjakan oleh siswa berkebutuhan khusus di kelas 4:

\subsection{0-14.00 WIB}

${ }^{16}$ Berdasarkan observasi kegiatan pembelajaran bahasa Arab di sekolah setiap hari senin pukul 
Gambar 4.1 Hasil Tulisan Mengerjakan Tugas Bahasa Arab siswa Bekebutuhan Khusus

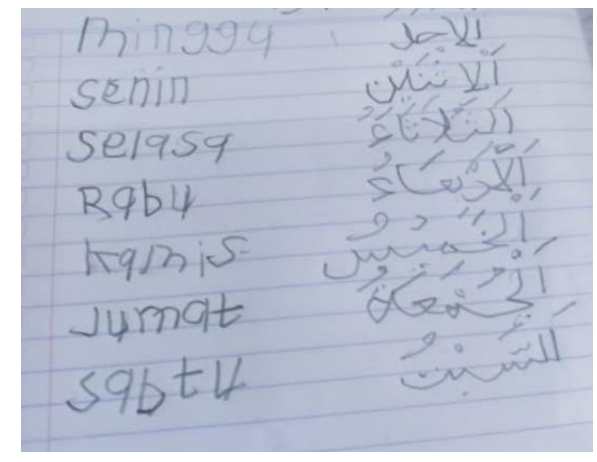

Seperti yang telah dijelaskan sebelumnya, pembelajaran untuk siswa berkebutuhan khusus telah mengalami penyesuaian dalam tujuan, bobot materi maupun tugas. Gambar di atas menunjukan bahwa siswa berkebutuhan khusus hanya diminta untuk menyalin tulisan 'nama-nama hari dalam bahasa Arab' dengan bantuan orang tua atau guru inklusif, kemudian menulis artinya tanpa harus menghafalnya.

Selain itu, penyusunan perangkat pembelajaran, siswa berkebutuhan khusus juga telah mempertimbangkan hasil asesmen dan/atau masukan melibatkan pihak-pihak terkait, seperti: GPK (shadow teacher), Guru Kelas, Dokter, orang tua dan lainnya. Penyusunan perangkat pembelajaran tersebut salah satunya dilakukan melalui diskusi yang dilakukan secara berkala untuk membahas perkembangan siswa berkebutuhan khusus. Dari diskusi tersebut pihak sekolah khususnya Guru kelas, Guru inklusif maupun Guru Bidang Studi dapat membuat inovasi pembelajaran yang tepat dan terus dikembangkan agar dapat memberikan pembelajaran yang maksimal kepada siswa berkebutuhna khusus, sebagaimana telah terlaksana pada rapat inklusif yang peneliti juga terlibat dalam rapat tersebut. ${ }^{17}$

Adapun cara sekolah dalam menyikapi situasi pandemi yang sedang melanda Indonesia dan kemudian mengharuskan pembelajaran dilaksanakan dari rumah adalah dengan memberlakukan sistem dalam jaringan (daring) sebagaimana dihimbau oleh Menteri Pendidikan. Sekolah mengadakan rapat membahas penugasan pembelajaran di rumah untuk siswa SD Pelita Bangsa GIS sebagai alternatif pembelajaran selama situasi belum memungkinkan karena pandemk Virus Covid-19. ${ }^{18}$ Rapat tersebut dilakukan sebagai antisipasi kondisi belajar yang sewaktu-waktu bisa berubah dan pembuatan perencanaan kegiatan belajar selama di rumah untuk siswa baik reguler maupun berkebutuhan khusus.

Sebagai bentuk rancangan pembelajaran selama proses daring untuk anak berkebutuhan khusus, Guru inklusif (shadow teacher) diarahkan untuk membuat 'manual program' khusus untuk siswa berkebutuhan khusus. Berikut adalah contoh manual program siswa berkebutuhan khusus di SD Pelita Bangsa GIS:

\footnotetext{
${ }^{17}$ Rapat inklusif pada tanggal 3 Februari 2020 di Ruangan Kepala Sekolah SD Pelita Bangsa GIS

${ }^{18}$ Rapat internal masa pandemi pada tanggal 16 Maret 2020
} 
Tabel 4.7 Contoh Manual Program untuk Siswa Berkebutuhan Khusus SD Pelita Bangsa GIS

\begin{tabular}{|c|c|c|c|c|c|}
\hline $\begin{array}{c}\text { Materi } \\
\text { Pembelajaran }\end{array}$ & $\begin{array}{l}\text { Indikator } \\
\text { Pencapaian }\end{array}$ & Verifikasi & PIC & $\begin{array}{c}\text { Dokumen } \\
\text { Terkait/ } \\
\text { Tool }\end{array}$ & $\begin{array}{c}\text { Waktu } \\
\text { Pelaksa } \\
\text { naan }\end{array}$ \\
\hline $\begin{array}{l}\text { Hafalan Doa } \\
\text { Harian }\end{array}$ & $\begin{array}{l}\text { 1. Siswa diharapkan } \\
\text { mampu } \\
\text { mengulang } \\
\text { hafalan doa-doa } \\
\text { harian (doa mau } \\
\text { makan, setelah } \\
\text { makan, tidur, } \\
\text { bangun tidur, } \\
\text { untuk orang tua, } \\
\text { kebaikan dunia } \\
\text { akhirat, sebelum } \\
\text { belajar) } \\
\text { 2. Orang tua } \\
\text { diharapkan untuk } \\
\text { mencatat dan } \\
\text { mendokumentasik } \\
\text { an amalan } \\
\text { kebaikan apa yang } \\
\text { siswa lakukan di } \\
\text { rumah untuk } \\
\text { dilaporkan kepada } \\
\text { Guru Pembimbing } \\
\text { (via whatsapp). }\end{array}$ & Wali kelas & $\begin{array}{l}\text { Guru } \\
\text { Pendamping }\end{array}$ & $\begin{array}{l}\text { Form catatan } \\
\text { untuk orang } \\
\text { tua yang } \\
\text { dikirimkan } \\
\text { oleh Guru } \\
\text { Pendamping } \\
\text { kepada orang } \\
\text { tua melalui } \\
\text { whatsapp. }\end{array}$ & \multirow[t]{2}{*}{$\begin{array}{l}\text { Dilakuk } \\
\text { an } \\
\text { secara } \\
\text { berkala } \\
\text { selama } 2 \\
\text { minggu } \\
\text { terhitun } \\
\text { g } \\
\text { tanggal } \\
30 \text { maret } \\
\text { hingaa } \\
10 \text { April } \\
2020 .\end{array}$} \\
\hline $\begin{array}{c}\text { Pembelaja-ran } \\
\text { Calistung }\end{array}$ & $\begin{array}{l}\text { 1. Siswa diharapkan } \\
\text { mampu membaca } \\
\text { teks berwarna } \\
\text { yang sudah } \\
\text { dikirimkan oleh } \\
\text { Guru Pendamping } \\
\text { kepada orang tua } \\
\text { melalui whatsapp. } \\
\text { 2. Siswa mampu } \\
\text { melakukan oprasi } \\
\text { hitungan dasar } \\
\text { seperti yang } \\
\text { diintruksikan pada } \\
\text { lembar kerja } \\
\text { (worksheet) yang } \\
\text { telah dikirimkan } \\
\text { oleh Guru } \\
\text { Pendamping } \\
\text { kepada orang tua } \\
\text { melalui whatsapp. } \\
\text { 3. Orang tua } \\
\text { diharapkan untuk } \\
\text { mencatat dan } \\
\text { mendokumentasik } \\
\text { an amalan } \\
\text { kebaikan apa yang } \\
\text { siswa lakukan di }\end{array}$ & Wali kelas & $\begin{array}{l}\text { Guru } \\
\text { Pendamping }\end{array}$ & $\begin{array}{l}\text { 1.Lembar } \\
\text { kerja } \\
\text { (worksheet) } \\
\text { calistung } \\
\text { dan } \\
\text { mewarnai } \\
\text { yang telah } \\
\text { dikirimkan } \\
\text { oleh Guru } \\
\text { Pendamping } \\
\text { kepada } \\
\text { orang tua } \\
\text { melalui } \\
\text { whatsapp. } \\
\text { 2.Form } \\
\text { catatan } \\
\text { untuk orang } \\
\text { tua yang } \\
\text { dikirimkan } \\
\text { oleh Guru } \\
\text { Pendamping } \\
\text { kepada } \\
\text { orang tua } \\
\text { melalui } \\
\text { whatsapp. }\end{array}$ & \\
\hline
\end{tabular}




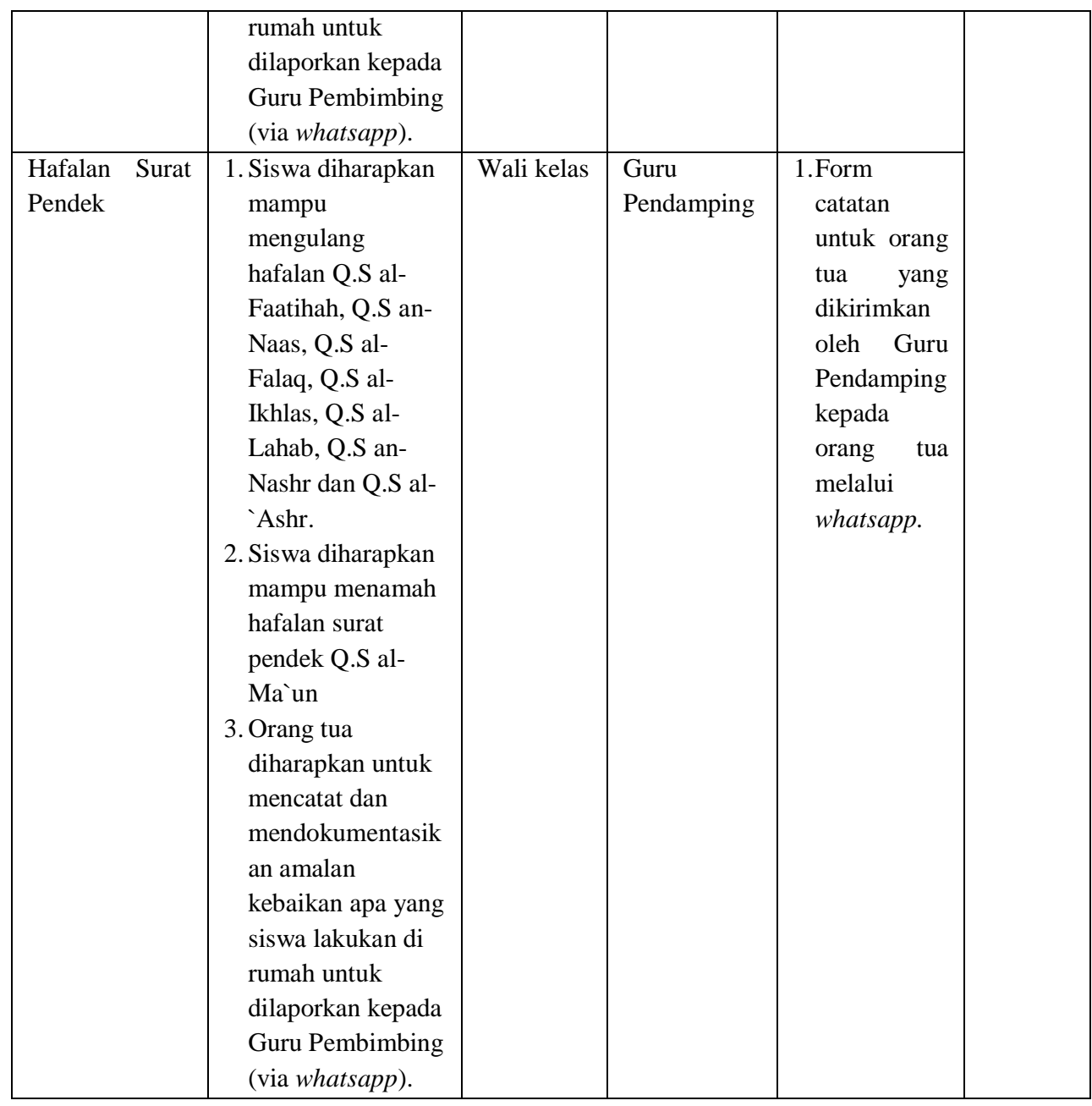

Setelah dianalisis, muatan materi dan indikator pencapaian yang dibuat untuk siswa berkebutuhan khusus ketika masa pandemi ini berbeda dengan pembelajarn biasanya ketika di sekolah. siswa berkebutuhan khusus lebih diarahkan untuk dapat membiasakan hal-hal terkait kemandirian dan spiritual. Pembelajaran daring menjadi sedikit kendala bagi Guru inklusif (shadow teacher) karena tidak bisa membimbing secara langsung masing-masing siswa berkebutuhan khusus. Namun demikian, 'manual program' dibuat agar menjadi acuan pembelajaran siswa berkebutuhan khusus yang tidak terlalu berat dan dapat dilakukan bersama dengan orang tuanya di rumah.

Berdasarkan paparan di atas, dapat disimpulkan bahwa SD Pelita Bangsa GIS telah berupaya melakukan perencanaan pembelajaran khususnya pada mata pelajaran Bahasa Arab yang tepat bagi siswa berkebutuhan khusus sebagaimana yang dijelaskan pada buku Pedoman Umum Penyelenggaraan Pendidikan inklusif oleh direktorat PPK-LK Pendidikan Dasar Kementerian Pendidikan dan Kebudayaan tahun 2014.

\section{Pelaksanaan Pembelajaran}

Jika dianalisis, SD Pelita Bangsa GIS ini menggunakan model kelas Kelas Reguler dengan Cluster dan Reguler atau istilah lain adalah kelas reguler dengan 
Guru Pembimbing Khusus (shadow teacher). ${ }^{19}$ Hal tersebut dilihat dari observasi langsung disekolah bahwa siswa berkebutuhan khusus belajar bersama siswa reguler di kelas reguler dalam kelompok khusus (artinya dalam bimbingan dan pengawasan Guru inklusif atau shadow teacher), dan dalam waktu-waktu tertentu ditarik dari kelas reguler ke ruang lain untuk belajar dengan guru pembimbing khusus. Pada intinya, semua kegiatan siswa berkebutuhan khusus baik di dalam kelas maupun di luar kelas selalu dalam bimbingan dan pengawasan Guru inklusif (shadow teacher). Jika Agung Setiawan menemukan sekolah Negeri penyelenggara program inklusif yang tidak menyediakan Guru inklusif sebagai pembimbing khusus, juga dengan jumlah siswa per kelas dengan rombongan belajar yang tidak sesuai dengan peraturan pemerintah, SD Pelita Bangsa GIS ini memberikan fasilitas Guru inklusif sebagai pembimbing khusus siswa berkebutuhan khusus selama pembelajaran berlangsung. Hal ini tentu saja menentukan bagaimana proses pembelajaran pendidikan inklusif tersebut dapat terlaksana dengan maskimal atau tidak. Lain dari pada itu, untuk menunjang pelaksanaan pembelajaran yang baik, setiap kelas juga hanya dibatasi maksimal 24 siswa termasuk siswa berkebutuhan khusus di dalamnya.

Terdapat beberapa hal yang harus diperhatikan dalam pelaksanaan pembelajaran di sekolah inklusif. ${ }^{20}$ Ms $\mathrm{MM}$ dalam wawancara virtual menyampaikan bahwa

Jadi, sebelum kita memberikan materi, kita menyediakan dulu medianya apa yang dibutuhkan oleh anak-anak. Biasanya setelah kita belajar bersama guru kelas, dan sudah menyelesaikan kegiatan.bisanya kita berikan memang materi tambahan. Nah itu yang menggunakan alat peraga alat bantu lainnya yang disesuaikan dengan kebutuhan khusus peserta. ${ }^{21}$

Selanjutnya beliau juga mempertegas bahwa

Jadi kita sebagai GPK atau shadow teacher melihat dulu eeee... kemampuan anak didik yang kita pegang sampai dimana, apa kemampuannya. Jadi kita berikan sesuai dengan kemampuan dia, tidak kita samakan dengan anak-anak regular. Dengan adanya kita shadow teacher atau GPK itu sangat membantu anak-anak belajar. ${ }^{22}$

Hal tersebut peneliti analisis dapat menjadi modalitas utama dalam menentukan bagaimana melakukan pembelajaran dengan siswa berkebutuhan khusus yang tentunya memiliki perbedaan satu sama lainnya. Selanjutnya, dapat dianalisis juga bahwa pembelajaran yang telah dimodifikasi tersebut telah disesuaikan dengan kemampuan dan karakteristik peserta didik berkebutuhan khusus dengan mengacu pada RPP siswa reguler. Penyesuaian tersebut meliputi:

\footnotetext{
${ }^{19}$ Perhatikan footnote no 66 dan 67 di BAB II

${ }^{20}$ Perhatikan footnot no 70 pada BAB II

21 Ms MM, Guru Pendamping Khusus (GPK)/Guru inklusif Kelas 1 SD Pelita Bangsa GIS, wawacara terstruktur pada hari Selasa, 14 April 2020 pukul 08.53 WIB WIB melalui WhatsApp Voice Not

${ }^{22}$ Ms MM, Guru Pendamping Khusus (GPK... melalui WhatsApp Voice Not
} 
a. Alokasi Waktu

Waktu pembelajaran Bahasa Arab untuk siswa berkebutuhan khusus di SD Pelita Bangsa GIS ini tidak sepenuhnya sama dengan siswa reguler. Ada kalanya mereka bisa belajar penuh waktu sama seperti siswa reguler, namun seringkali juga memerlukan waktu yang lebih sedikit. Hal tersebut memperhatikan kesiapan ataupun keadaan siswa berkebutuhan khusus bertepatan dengan waktu pembelajaran. Tentunya siswa berkebutuhan khusus satu dan lainnya memiliki porsi waktu belajar yang tidak sama.

Untuk kelas atas ${ }^{23}$ siswa reguler pelajaran Bahasa Arab mulai pada pukul 13.30-14.30 WIB. Adapun siswa berkebutuhan khusus sebagian hanya belajar hingga pukul 13.00 WIB, artinya siswa tersebut sudah pulang sebelum memasuki jam pelajaran Bahasa Arab. Pembelajaran digantikan pada hari lain ketika muatan pembelajaran yang lain ringan untuk siswa terssebut. Selain itu dapat juga diganti dengan penugasan yang sifatnya kognisi dasar seperti menulis dan meniru melafalkan kosa kata Bahasa Arab. Satu siswa berkebutuhan khusus lainnya mengikuti pembelajaran di kelas dengan melalui pendampingan guru inklusif hingga pukul 14.30 WIB.

b. Isi/materi

Tema untuk materi pembelajaran Bahasa Arab antara siswa reguler dan siswa berkebutuhan khusus di SD Pelita Bangsa GIS disamakan. Akan tetapi siswa berkebutuhan khusus mendapatkan materi yang lebih sederhana dan mendapat bimbingan langsung dari Guru inklusif (shadow Teacher) ketika pembelajaran berlangsung. Dalam RPP Bahasa Arab kelas 4 untuk siswa reguler dijelaskan materi آَنَْْsُ الأَسَّامُ bertujuan untuk membedakan bunyi hurufhuruf hijaiyah berkaitan dengan mufrodat tentang آنَمَاءُ الآَيَّامُ dengan benar, melafalkan mufrodat tentang آَسمْاءُ الأَيَّامُ dalam bahasa Arab dengan benar, menyebutkan mufrodat tentang آَنْمَاءُ الآَيَّامُ dengan benar, meniru bunyi huruf-huruf hijaiyah berkaitan dengan mufrodat tentang آسَمْماءُ الآَيَّامُ dan Mendemonstrasikan bunyi huruf-huruf hijaiyah berkaitan dengan mufrodat tentang آسمْماءُ الآَيَّامُ Namun untuk siswa berkebutuhan khusus dibatasi hanya mengucapkan nama-nama hari dalam bahasa Arab dengan bimbingan shadow teacher, menuliskan nama-nama hari dalam bahasa Arab dengan atau tanpa bimbingan shadow teacher dan menghafal minimal 2 nama hari dalam Bahasa Arab.

c. Proses Belajar-Mengajar

Proses belajar mengajar untuk siswa berkebutuhan khusus dilakukan kondisional baik tempat, materi maupun porsi waktunya. Di SD Pelita Bangsa GIS siswa berkebutuhan khusus tidak dipaksakan untuk menerima pembelajaran Bahasa Arab yang sama dengan siswa reguler, namun disesuaikan dengan kemampuannya melalui bimbingan Guru inklusif (shadow teacher).

${ }^{23}$ Kelas 4,5 dan 6 SD Pelita Bangsa GIS 
d. Media, Bahan dan Sarana-Prasarana

Sebelum pelaksanaan pembelajaran, Guru kelas maupun Guru bidang studi tentunya telah mempersiapkan media, bahan dan sarana-prasarana untuk seluruh siswa. Namun untuk materi-materi tertentu yang memerlukan penyederhanaan dan penyesuaian media, Guru kelas maupun Guru bidang studi akan berkoordinasi dengan Guru inklusif (shadow teacher) terkait penggunaan media. Media dapat disediakan oleh Guru kelas atau Guru bidang studi dan pada pelaksanaannya dibantu oleh shadow teacher atau sejak awal media disiapkan oleh shadow teacher.

e. Lingkungan belajar

Guru kelas dan shadow teacher setiap harinya selalu menjaga situasi atau suasana kelas agar dapat menjadi lingkungan belajar yang nyaman bagi seluruh siswa baik reguler maupun berkebutuhan khusus. Di SD Pelita Bangsa GIS, tidak terdapat bullying atau diskriminasi terhadap siswa berkebutuhan khusus dalam pembelajaran. Guru-guru dan pihak sekolah selalu memberikan penjelasan terkait keberagaman dan pentingnya toleransi, dimanapun dan kapanpun. Sehingga semua masyarakat di sekolah telah bersinergi menciptakan lingkungan belajar yang nyaman bagi seluruh siswa.

f. Pengelolaan Kelas

Di SD Pelita Bangsa GIS, Guru Kelas dan shadow teacher selalu bersinergi untuk melakukan pengelolaan kelas yang baik. Keduanya saling berkerja sama dan bantu-membantu satu sama lain. Pengelolaan kelas dilakukan dengan baik, salah satunya dengan membuat posisi duduk siswa yang diubah secara berkala. Menempatan posisi duduk siswa mempertimbangkan kebiasaan dan gaya belajar siswa. Siswa berkebutuhan khusus ditempatkan berdekatan dengan tempat duduk shadow teacher. Selain itu, ketika pembelajaran dilaksanakan, siswa berkebutuhan khusus juga tetap diajak untuk berinteraksi oleh Guru Kelas maupun teman-temannya, sehingga dalam pengelolaan kelas yang baik, siswa berkebutuhan khusus juga dapat berkembang secara kemampirian maupun sikap dan emosinya. Hal tersebut tidak terlepas dari pemantauan shadow teacher.

Pelaksanaan pembelajaran di SD Pelita Bangsa GIS ini dinilai lebih kondusif dari pembelajaran yang dilakukan disekolah Negeri penyelenggara program inklusif di Tangsel. Hal tersebut ditandai dengan beberapa hal berikut dari hasil observasi langsung di sekolah ${ }^{24}$ :

a. Guru baik Guru Kelas, Guru Bidang Studi maupun Guru inklusif (shadow teacher) telah melakukan komunikasi yang interaktif dengan seluruh siswa. Di sekolah ini, siswa berkebutuhan khusus selalu diajak berkomunikasi untuk merangsang kemampuan interaksi siswa.

b. Guru-guru menyajikan materi bahan pelajaran dengan didukung metode, sumber belajar, dan bahan latihan yang sesuai dengan tujuan pembelajaran. Buku paket sebagai sumber belajar siswa sudah disediakan oleh sekolah baik

\footnotetext{
${ }^{24}$ Observasi langsung kegiatan pembelajaran di sekolah
} 
untuk siswa reguler maupun berkebutuhan khusus. Hanya saja, buku khusus untuk membantu pembelajaran siswa berkebutuhan khusus belum tersedia, sehingga pada prakteknya, Guru inklusif (shadow teacher) yang berinovasi membuat media atau sumber belajar yang dapat dipahami oleh siswa. Walaupun demikian, semua komponen yang diperlukan untuk membuat media ataupun sumber belajar siswa berkebutuhan khusus dapat dikoordinasikan dengan pihak TU dan agar kemudian dapat segera disediakan sesuai kebutuhan dan permintaan dari Guru inklusif (shadow teacher).

c. Siswa berkebutuhan khusus selalu dilibatkan dalam setiap kegiatan. Seperti yang disampaikan Ms TE,

Kegiatan-kegiatan di sekolah maupun di luar seperti outbond, fieldtrip atau apapun itu tetap dilibatkan. Karena dari kegiatan itu siswa berkebutuhan khusus dilatih kemandiriannya. Yang membedakan adalah jika kegiatan di dalam sekolah biasanya dua siswa berkebutuhan khusus didampingi satu Guru inklusif (shadow teacher), ketika kegiatan di luar sekolah, satu siswa didampingi oleh satu guru. Kemudian, jika ada kegiatan pentas di sekolah seperti 'assembly' yang setiap tahun selalu diadakan, siswa berkebutuhan khsus tetap ditampilkan. Pihak sekolah tidak membedakan anak berkebutuhan khusus dengan anak reguler. ${ }^{25}$

Hal ini juga diperkuat dengan dokumentasi foto kegiatan Assembly 2020 yang melibatkan siswa berkebutuhan khusus. Berikut adalah salah satu dokumentasi kegiatan tersebut:

Gambar 4.2 Kegiatan Assembly 2020 melibatkan siswa berkebutuhan khusus

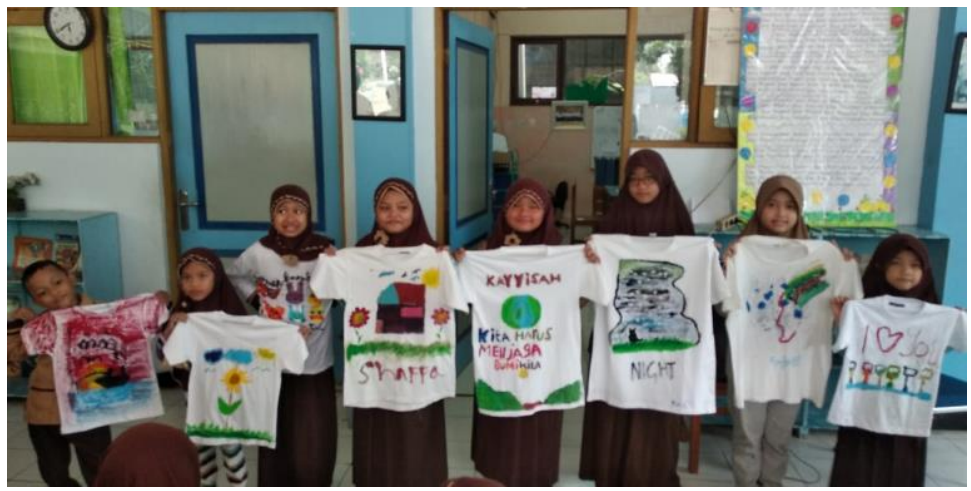

Dokumentasi di atas menunjukan bahwa SD Pelita Bangsa GIS selalu melibatkan siswa berkebutuhan khusus dalam setiap kegiatan pembelajaran, baik di dalam maupun di luar kelas.

d. Materi untuk siswa berkebutuhan khusus disampaikan dengan bahasa atau istilah yang dekat dengan kehidupan sehari-hari. Hal tersebut dilakukan supaya mudah dipahami oleh siswa berkebutuhan khusus. Selain itu siswa berkebutuhan khusus juga seringkali diikut sertakan dalam pembelajar kelompok.

${ }^{25}$ Ms TE, Wali Kelas di SD Pelita Bangsa GIS, wawancara terstruktur pada hari Rabu, 29 April 2020 pukul 20.20 WIB melalui WhatsApp Vice Not.

111 | Itsam Samrotul F. dan Esi Hairani: Implementasi Pembelajaran Insklusif,... 
Selain itu, melalui pengamatan secara langsung di lapangan, pelaksanaan pembelajaran inklusif khususnya dalam mata pelajaran Bahasa Arab telah dilakukan sesuai dengan penyesuaian yang tepat dengan hambatan setiap siswa berkebutuhan khusus di kelas 4. Seperti yang tercantum dalam tabel $2.1^{26}$ guru mata pelajaran dan guru inklusif telah melakukan penyesuaian proses (pelaksanaan) pembelajaran untuk siswa dengan hambatan kecerdasan yaitu dengan menggunakan obyek-obyek nyata dalam penjelasan konsep atau materi pembelajaran, menyajikan materi pembelajaran dengan penjelasan yang lebih sederhana, pembelajaran lebih ditekankan pada kompetensi-kompetensi fungsional (skill) yang dibutuhkan untuk kemandirian dalam aktivitas kehidupan seperti mengambil dan merapikan kembali buku dan alat tulis untuk belajarmdan Pemberian materi dan tugas-tugas yang kadarnya lebih mudah.

Dalam situasi pandemik, pembelajaran di rumah tetap terlaksana dengan baik. Ini dapat dianalisis dari hasil rapat virtual evaluasi kegiatan pembelajaran dan program-program selama berlaku sistem daring. Walaupun pembelajaran di rumah sedikit menjadi kendala untuk siswa-siswa berkebutuhan khusus yang berada di kelas bawah karena pendampingan tidak bisa dilakukan secara langsung, sekolah memiliki alternatif lain untuk memberikan program pembelajaran khususnya bagi siswa berkebutuhan khusus. Program tersebut adalah:

b. Guru inklusif memberikan pendampingan langsung di sekolah seminggu sekali atau seminggu $2 x$ dengan jam yang sudah dijadwalkan. Ini dilakukan sebagai upaya memaksimalkan pembelajaran. Dengan catatan, semua protocol kesehatan dan pencegahan Covid-19 tetap dilaksanakan.

c. Diskusi dan konsultasi online orang tua siswa berkebutuhan khusus dengan dokter yang telah disiapkan oleh sekolah terkait perkembangan pendidikan siswa berkebutuhan khusus dan strategi orang tua dalam mendampingi belajar siswa tersebut selama belajar di rumah. ${ }^{27}$

Di sekolah inklusif -dalam hal ini SD Pelita Bangsa GIS, pembelajaran dilakukan dengan mengakomodasi semua kebutuhan siswa di kelas yang bersangkutan, termasuk membantu mereka memperoleh pemahaman yang sesuai dengan gaya belajarnya masing-masing. Setiap guru yang mendapatkan tugas untuk memberikan pembelajaran tentu saja tidak boleh menyamaratakan cara mengajar untuk semua siswa. Hal tersebut relevan dengan apa yang ditulis oleh Dr. Dadang Garnida dalan buku Pengantar Pendidikan inklusif, bahwa selain prinsip-prinsip umun, prinsip kekhususan siswa juga harus dipahami semua guru. Bukan hanya Guru inklusif (shadow teacher)nya saja.

Ms TE menyampaikan bahwa,

26 Tabel 2.1 di BAB II halaman 42

${ }^{27}$ Rapat Wali Kelas dan Guru inklusif (shadow teacher) pada hari Selasa, 12 Mei 2020 Pukul 11.00 WIB Via Google Meeting 
Untuk sekarang, Alhamdulillah untuk ST bisa mengikuti dengan anak regular lainnya. Karena orang tua ST mendampingi seutuhnya, jadi ST bisa mengikuti dengan anak regular lainnya. Sebelumya saya sudah menyampaikan kepada orang tuanya, kalau misalnya ada kesulitan, bisa saya sesuaikan bisa saya bantu. Alhamdulillah tidak ada kesulitan. Hana saja ST suka capek jadi waktunya tidak bisa disamakan dengan anak relguler lainnya. Kalau misalkan anak regular lainnya jam 3 sudah selesai, ST bisa dijeda, jadi malamnya baru ngerjain. Tapi saya memaklumi aja, kalau misalkan sudah tidak bisa, gausah dipaksakan. Tapi Alhamdulillah masih bisa mengikuti. Untuk FS itu diberikan tugas oleh Guru Pendamping. Jadi dari awal sampai sekarang diberikan tugas oleh Guru Pendamping berupa gambar dan tulisan tulisan menebalkan hitunganhitungan 1-10, alphabet. Seperti itu, jadi pembelajarannya dibedakan dengan anak regular lainnya, tapi tetap sesuai tema. Seperti itu. ${ }^{28}$

Pembelajaran dilaksanakan sesuai dengan kemampuan siswa berkebutuhan khusus yang berkaitan. Pembelajaran tersebut dilakukan secara kondisional. Artinya, sebagaian besar dilaksanakan di dalam kelas bersama dengan anak reguler lainnya, dan sesekali dilaksanakan di dalam Happy Room apabila sesekali diperlukan. Adapun dalam situasi pandemik, siswa berekbutuhan khusus belajar bersama orang tua di rumahnya dengan durasi waktu dan materi yang sudah disederhanakan. Berikut adalah dokumentasi kegiatan pembelajaran di rumah untuk siswa berkebutuhan khusus:

Gambar 4.3 Pembelajaran Online Masa Pandemik

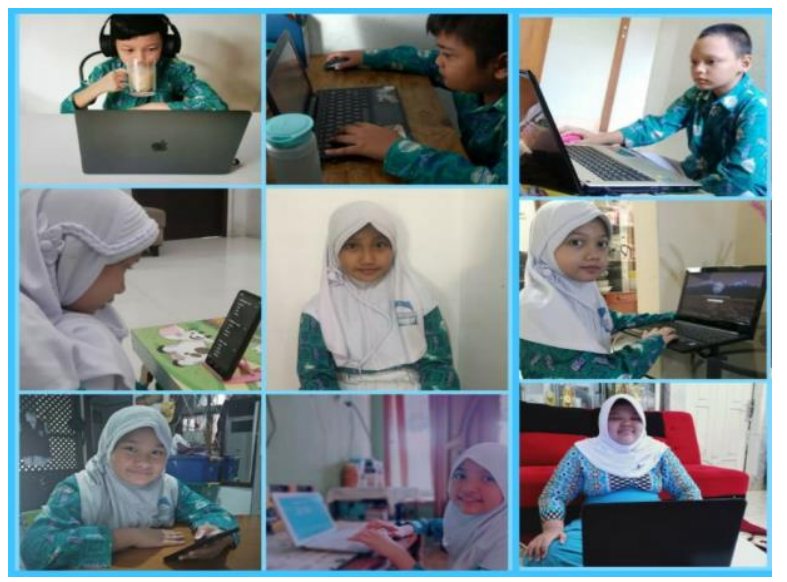

Selain pembelajaran yang menunjang perkembangan pengetahuan dan kemandirian, SD Pelita Bangsa GIS juga melaksanakan program pembelajaran spiritual untuk menunjang keseimbangan perkembangan siswa berkebutuhan khusus. Berikut adalah program spiritual keislaman yang dilakukan secara berkala di SD Pelita Bangsa GIS sebagaimana dijelaskan Kepala Sekolah dalam rapat internal guru inklusif:

${ }^{28}$ Ms TE, Wali Kelas di SD Pelita Bangsa GIS, wawancara terstruktur pada hari Rabu, 29 April 2020 pukul 20.20 WIB melalui WhatsApp Vice Not.

113 | Itsam Samrotul F. dan Esi Hairani: Implementasi Pembelajaran Insklusif,... 
b. Shalat dluha setiap hari. Shalat dluha untuk siswa berkebutuhan khusus dilakukan di happy room sementara siswa reguler shalat di kelas atau di mushola sekolah. Selain itu, bacaan shalat untuk siswa berkebutuhan khusus wajib dikeraskan (dijahrkan) agar dapat diikuti dan dihafalkan perlahan oleh siswa yang bersangkutan. kemudian bacaan shalat untuk gerakan rukuk dan sujud dianjurkan dibaca lebih banyak. Hal itu dilakukan sebagai terapi untuk siswa berkebutuhan khusus agar mampu belajar konsentrasi dan menahan gerak tubuh untuk beberapa saat.

c. Siswa berkebutuhan khusus diwajibkan untuk berwudlu setiap sebelum belajar.

d. Guru inklusif membimbing siswa berkebutuhan khusus untuk membaca dan menghafal Q.S Al-Baqoroh 1-5 dan 285-286, Ayat Kursi, Q.S al-Ikhlas, Q.S alFalaq serta Q.S an-Nas. Bacaan tersebut dibimbing secara bertahap setiap hari.

e. Guru inklusif secara konsisten memberikan Pekerjaan Rumah (PR) kepada siswa berkebutuhan khusus untuk melakukan amal sholeh kepada orang tua, keluarga dan teman sejawat. Kemudian dibantu oleh orang tua untuk menuliskan amal sholeh yang telah dilakukan tersebut.

f. Pelajaran Tahsin untuk siswa berkebutuhan khusus dibimbing langsung oleh Guru inklusif.

g. Pendampingan optimal oleh Guru inklusif salah satunya dengan berupaya untuk perbanyak istigfar. ${ }^{29}$

Di bawah ini adalah salah satu kegiatan shalat berjamaah siswa sebagaibentuk pembelajaran spiritual untuk siswa berkebutuhan khusus ketika pembelajaran di sekolah:

Gambar 4.4 Kegiatan Shalat Dzuhur Berjamaah

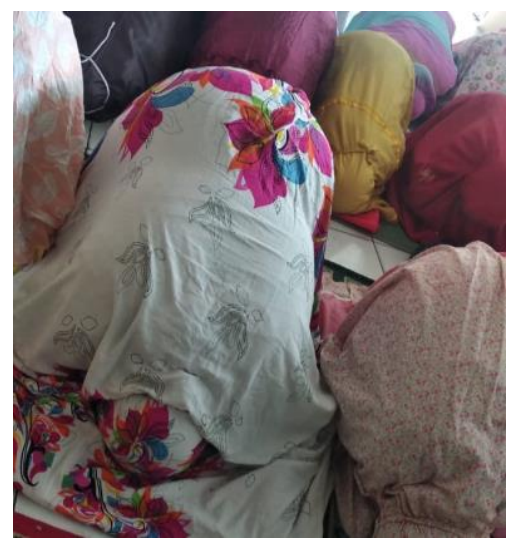

Desain pembelajaran yang dimiliki SD Pelita Bangsa GIS ini dinilai memiliki kelebihan karena menyertakan pendekatan-pendekatan spiritual. Sekolah ini menyiapkan program-program spiritual khusus untuk siswa berkebutuhan khusus sebagai program tambahan dari rangkaian kurikulum yang telah ada. Program spiritual keislaman tersebut bertujuan untuk menumbuhkan sikap (akhlak), spiritualitas keagamaan serta perkembangan otak dan karakter siswa berkebutuhan khusus di SD Pelita Bangsa GIS.

${ }^{29}$ Rapat inklusif pada tanggal 3 Februari 2020 di Ruangan Kepala Sekolah SD Pelita Bangsa GIS 
Berdasarkan analisis data penelitian diatas dapat disimpulkan bahwa pelaksanaan pembelajaran inklusif khususnya pada mata pelajaran Bahasa Arab di SD Pelita Bangsa GIS telah dilakukan dengan baik. Sekolah juga telah memberikan pembelajaran dengan kompetensi-kompetensi fungsional (skill) yang dibutuhkan untuk kemandirian dalam aktivitas kehidupan serta pembiasaan-pembiasaan spiritual untuk menumbuhkan sikap (akhlak), spiritualitas keagamaan serta perkembangan otak dan karakter siswa berkebutuhan khusus.

\section{Sistem Penilaian dan Pelaporan}

Penilaian hasil belajar pada Kurikulum 2013 ini dilakukan oleh pendidik dan satuan pendidik melalui tahapan mengkaji silabus sebagai acuan perencanaan penilaian, pembuatan kisi-kisi instrumen dan penetapan kriteria penilaian, pelaksanaan penilaian dalam proses pembelajaran, menganalisis hasil penilaian dan memberi tindak lanjut atas penilaian yang dilakukan oleh pendidik, menyusun laporan hasil penilaian dalam bentuk deskripsi pencapaian kompetensi dan deskripsi sikap.

Penilaian untuk siswa program inklusif berbeda dengan siswa reguler. SD Pelita Bangsa GIS memiliki instrumen penilaian khusus yang dibuat secara ekskulif oleh Dokter sekaligus Pembina program inklusif di Yayasan Pelita Bangsa. Penilaian menggunakan instrumen itu dilakukan untuk mengetahui perkembangan siswa berkebutuhan khusus dengan menilai lima (5) aspek perkembangan yang berbeda. Kelima aspek tersebut adalah:

f. Bina Kognisi Dasar meliputi: sistem keseimbangan, motorik kasar, motorik halus, daya tangkap, daya balas, bahasa, prilaku dan sikap serta mandiri sosial.

g. Bina Didik (bimbingan belajar) meliputi: Perkembangan calistung dan perkembangan hasil belajar.

h. Bina Sosial (bimbingan sosial) meliputi: kooperatif terhadap peraturan, pengendalian emosi, kemandirian dan tanggung jawab.

i. Bina Diri (bimbingan keterampilan) meliputi: merapikan alat dan buku tulis, memakai dan melepas sepatu, membuka dan menutup botol, merapikan peralatan makan, serta memakai dan melepas baju.

j. Bina Sehat (bimbingan kesehatan) meliputi: kesehatan penglihatan, kesehatan pendengaran dan gizi. ${ }^{30}$

Tabel 4.8 Contoh Instrumen Penilaian Perkembangan Siswa Berkebutuhan Khusus $^{31}$.

\begin{tabular}{|l|l|l|l|l|l|}
\hline \multicolumn{5}{|l|}{ A. SISTEM KESEIMBANGAN } \\
\hline a. & Reaksi Bobot Badan & 1 & 3 & 6 & 9 \\
\hline & Angkat satu kaki dengan mtutup mata
\end{tabular}

\footnotetext{
${ }^{30}$ Dr BGS, Pembina Program inklusif di Yayasan Pelita Bangsa, wawacara terstruktur pada hari Rabu, 29 Juni 2020 pukul 20.20 WIB WIB melalui WhatsApp Call

${ }^{31}$ Instrumen lengkapnya lihat di lampiran
} 


\begin{tabular}{|l|l|c|c|c|c|}
\hline & Melompat mundur dengan satu kaki diangkat & 1 & 3 & 6 & 9 \\
\hline & Berjalan mundur diatas garus atau balok titian & 1 & 3 & 6 & 9 \\
\hline & Berjalan mundur menaiki tangga & 1 & 3 & 6 & 9 \\
\hline b. & Reaksi Koordinasi Tubuh & & & \\
\hline & Telentang mata tertutup mempertemukan kedua jempol kaki & 1 & 3 & 6 & 9 \\
\hline & $\begin{array}{l}\text { Telungkup di meja, kaki bergantungan mempertemukan kedua jempol } \\
\text { kaki }\end{array}$ & 1 & 3 & 6 & 9 \\
\hline & Mempertemukan ujung jari kedua tangan di belakang & 1 & 3 & 6 & 9 \\
\hline & Melompat-lompat ke depan di atas dua keset yang dipindahkannya & 1 & 3 & 6 & 9 \\
\hline \multicolumn{1}{|l|}{ B. MOTORIK KASAR } & & & \\
\hline
\end{tabular}

\section{B. MOTORIK KASAR}

\begin{tabular}{|c|c|c|c|c|c|}
\hline a. & Sikap Tubuh & & & & \\
\hline & Melempar dan menangkat bola & 1 & 3 & 6 & 9 \\
\hline & Menggerakan anggota badan menyilang & 1 & 3 & 6 & 9 \\
\hline b. & Tonus & & & & \\
\hline & Tidur telentang mengangkat-angkat perut & 1 & 3 & 6 & 9 \\
\hline c. & Rancang Motorik & & & & \\
\hline & Melakukan gerakan yang tidak dikenal sebelumnya & 1 & 3 & 6 & 9 \\
\hline d. & Orientasi Diri & & & & \\
\hline & Menutup mata kanan kemudian kiri & 1 & 3 & 6 & 9 \\
\hline & Mengangkat kaki kanan kemudian kiri & 1 & 3 & 6 & 9 \\
\hline & Mengangkat tangan kanan kemudian kiri & 1 & 3 & 6 & 9 \\
\hline
\end{tabular}

\section{MOTORIK HALUS}

\begin{tabular}{|c|c|c|c|c|c|}
\hline \multirow[t]{2}{*}{ a. } & \multicolumn{5}{|l|}{ Koordinasi Mata dan Telinga } \\
\hline & Menggunting kertas sesuai gambar & 1 & 3 & 6 & 9 \\
\hline & Meronce manik-manik & 1 & 3 & 6 & 9 \\
\hline & Memutar benda dengan jari-jari satu tangan & 1 & 3 & 6 & 9 \\
\hline \multirow[t]{3}{*}{ b. } & \multicolumn{5}{|l|}{ Graphmotor } \\
\hline & Menggunakan pensil menggambar persegi empat, segitiga, lingkaran & 1 & 3 & 6 & 9 \\
\hline & Menghapus gambar mulai persegi empat, segitiga kemudian lingkaran & 1 & 3 & 6 & 9 \\
\hline \multirow[t]{2}{*}{ c. } & \multicolumn{5}{|l|}{ Visualmotor } \\
\hline & Mengikuti dengan mata gerakan pensil & 1 & 3 & 6 & 9 \\
\hline \multirow[t]{2}{*}{ d. } & \multicolumn{5}{|l|}{ Verbalmotor } \\
\hline & Menggoyang rahang, menjulurkan lidah & 1 & 3 & 6 & 9 \\
\hline
\end{tabular}

116 | Itsam Samrotul F. dan Esi Hairani: Implementasi Pembelajaran Insklusif,... 
Selain penilaian seperti diuraikan di atas, penilaian lain juga diakumulasikan dengan hasil laporan kegiatan dan perkembangan harian siswa yang ditulis oleh Guru inklusif (shadow teacher).Khusus untuk penilaian pembelajaran siswa berkebutuhan khusus, Kriteria Ketuntasan Minimum (KKM) yang digunakan tidak disamakan dengan siswa reguler. Kegiatan ini dilakukan secara berkala dan selalu rutin dibahas dalam pertemuan khusus guru pendamping khusus (shadow teacher) dengan kepala sekolah dan tenaga professional. Laporan perkembangan siswa berkebutuhan khusus dilakukan tiga bulan sekali.

Dalam penentuan Kriteria Ketuntasan Minimum (KKM) Ms MM menuturkan bahwa,

Guru-guru akan melihat terlebih dulu anak berkebutuhan khusus secara individu, apakah dia bisa mengikuti pembelajarn reguler atau tidak. Jika siswa tersebut mampu mengikuti pembelajaran reguler maka KKM nya disamakan dengan anak reguler, tetapi tetapi jika siswa tersbut tidak mampu mengikuti maka kita berikan KKM dibawah reguler misalnya 50 atau 60 seperti itu. ${ }^{32}$

Berikut adalah contoh tabel hasil belajar yang ada pada laporan hasil belajar siswa berkebutuhan khusus di SD Pelita Bangsa GIS

Tabel 4.9 Contoh Leger KI.3 Laporan Hasil Belajar Mata Pelajaran Bahasa Arab Siswa Berkebutuhan Khusus kelas 4

\begin{tabular}{|c|c|c|c|c|c|c|c|}
\hline \multirow{2}{*}{ No } & \multirow{2}{*}{ Nama Lengkap } & \multirow{2}{*}{ Pelajaran } & \multirow{2}{*}{ KKM } & \multirow{2}{*}{ Nilai } & \multicolumn{3}{|c|}{ Predikat } \\
\hline & & & & & Huruf & Ket & Pujian \\
\hline 1 & STH & \multirow{3}{*}{$\begin{array}{c}\text { Bahasa } \\
\text { Arab }\end{array}$} & 65 & 75 & B & Baik & Alhamdulillah \\
\hline 2 & WLD & & 70 & 89 & A & Amat Baik & Masya Allah \\
\hline 3 & FS & & 65 & 73 & $\mathrm{C}$ & Cukup & Alhamdulillah \\
\hline
\end{tabular}

Dari tabel tersebut dapat diketahui bahwa KKM yang ditentukan untuk siswa berkebutuhan khusus berbeda dengan siswa reguler. Siswa berkebutuhan khusus tidak dipaksa untuk dapat memiliki dan mencapai nilai yang tinggi seperti yang ditargetkan pada siswa berkebutuhan khusus. Modifikasi atau penyesuaian penilaian seperti itu membuat hasil penilaian yang cukup representatif terhadap hasil belajar siswa berkebutuhan khusus sebagaimana adanya. Nilai akhir yang

32 Ms MM, Guru Pendamping Khusus (GPK)/Guru inklusif Kelas 1 SD Pelita Bangsa GIS, wawacara terstruktur pada hari Selasa, 14 April 2020 pukul 08.53 WIB WIB melalui WhatsApp Voice Not 
ditulis pada laporan hasil belajar adalah akumulasi dari keseluruhan nilai proses hingga penilaian akhir yaitu dengan rincian $20 \%$ nilai rata-rata tugas, $30 \%$ rata-rata nilai Penilaian Harian (UH/PH), 20\% nilai hasil PTS (Penilaian Tengah Semester) dan $40 \%$ nilai PAT (Penilaian Akhir Semester). ${ }^{33}$ Tabel diatas juga memberikan informasi bahwa kedua siswa berkebutuhan khusus di kelas 4 telah tuntas mengikuti pembelajaran dengan nilai diatas KKM siswa berkebutuhasn khusus. Keduanya mendapatkan akumulasi nilai yang cukup dan baik sehingga menunjukan bahwa siswa berkebutuhan khusus tersebut telah mampu mengikuti pembelajaran sesuai dengan kemampuannya masing-masing.

Berdasarkan penilaian-penilaian seperti yang dijelaskan di atas, pihak sekolah dapat melalukan inovasi pembelajaran kedepannya agar siswa yang bersangkutan dapat mengalami perkembangan yang lebih baik.

Adapun sistem pelaporan yang dilakukan oleh SD Pelita Bangsa GIS adalah berdasarkan penilaian yang dilakukan setiap sebulan sekali dalam bentuk observasi. Hasil penilaian tersebut kemudian akan dibuatkan laporan berbentuk grafik dan dinarasikan sesuai dengan perkembangan yang terjadi dalam tiga bulan terakhir. Berikut adalah contoh grafik penilaian hasil belajar dan perkembangan siswa berkebutuhan khusus per tiga bulan sekali yang kemudian akan dijadikan laporan pembelajaran dan perkembangan di SD Pelita Bangsa GIS:

Grafik 4.1 contoh grafik penilaian hasil belajar dan perkembangan siswa berkebutuhan khusus per tiga bulan sekali di SD Pelita Bangsa GIS

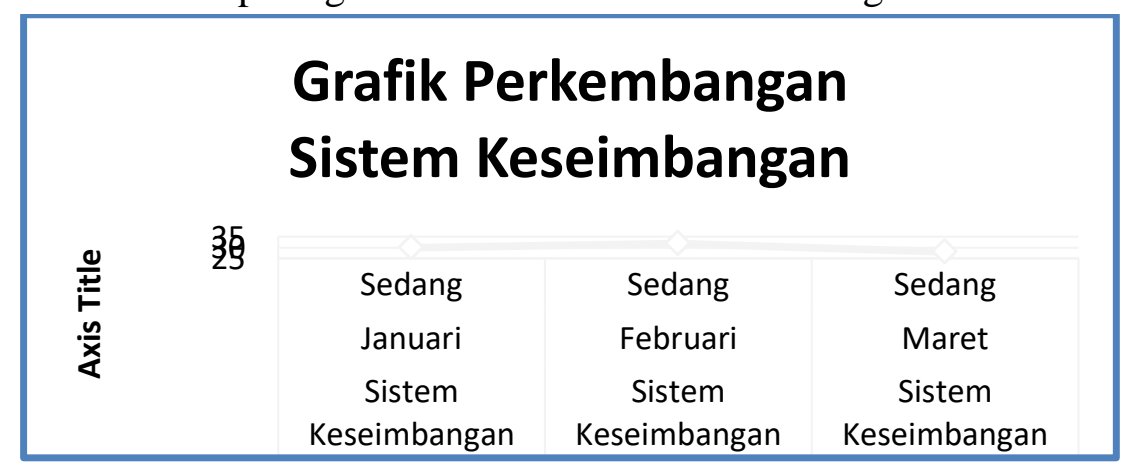

Adapun menindaklanjuti pembelajaran daring, sekolah telah berupaya untuk memodifikasi sistem penilaian dan pelaporan. hal tersebut dilakukan karena kondisi pembelajaran yang dilakukan di rumah sehingga menjadi kendala bagi guru inklusif untuk dapat mendeskripsinya bagaimana perkembangan siswa berkebutuhan khusus secara rinci. Oleh karena itu, selain penilaian hasil belajar, sekolah juga menyiapkan sistem penilaian dan pelaporan perkembangan siswa berkebutuhan khusus dengan terfokus pada 8 aspek perkembangan.

Adapun dalam pelaporan hasil belajar siswa berkebutuhan khusus, Ms TE menuturkan bahwa,

Sekolah tetap memakai raport seperti anak reguler. Kalau untuk laporan hasil belajar kita tetap memakai raport seperti anak reguler. Kalau untuk anak inklusif, ada laporan lain selain laporan hasil belajar. Yaitu laporan

\footnotetext{
${ }^{33}$ Berdasarkan file format penilaian untuk Guru Mata Pelajaran (bidang studi) SD Pelita Bangsa GIS, Tangerang Selatan
} 
perkembangan kemandirian, emosional, motoric kasar, motoric halus dan lain-lain. Dan itu akan dicatat ole GPK selama setiap hari. Perkembangannya itu dicatat. Nah ada juga penilaian yang dilakukan setiap sebulan sekali berbentuk observasi. Jadi GPK mengobservasi anak untuk loncat, bermain bola, mewarnai, menggunting dan lain-lain. Dan dalam tiga bulan observasi itu akan digabungkan menjadi sebuah bagan. ${ }^{34}$

Dari paparan diatas, dapat dianalisis bahwa proses penilaian terhadap perkembangan siswa berkebutuhan khusus di SD Pelita Bangsa GIS dilaksanakan setiap hari (catatan pribadi tentang perkembangan siswa berkebutuhan khusus). Penilaian tersebut akan diakumulasikan dengan penilaian perkembangan setiap hari dilakukan sebulan sekali serta memberikan siswa berkebutuhan khusus 2 bentuk laporan yaitu laporan hasil belajar dan laporan perkembanganyang dilakukan per 3 bulan

Berdasarkan hasil analisis diatas, dapat disimpulkan bahwa SD Pelita Bangsa GIS telah melakukan penilaian dan pelaporan yang relevan dengan apa yang seharusnya dilakukan oleh sekolah penyelenggara program inklusif. Penilaian hasil belajar siswa berkebutuhandalam mata pelajaran Bahasa Arab dilakukan melalui penyesuaian terhadap KKM yang telah ditentukan. Hal unik yang dimiliki sekolah ini adalah memiliki instrumen peniliaian yang berbeda dengan sekolah pada umumnya dan disusun khusus oleh tim inklusif sekolah.

\section{KESIMPULAN}

Berdasarkan hasil analisis menjawab rumusan masalah tentang implementasi pembelajaran inklusif di SD Pelita Bangsa Global Islamic School (GIS), Tangerang Selatan, peneliti menyimpulkan bahwa: SD Pelita Bangsa GIS telah berupaya melakukan perencanaan pembelajaran khususnya pada mata pelajaran Bahasa Arab yang tepat bagi siswa berkebutuhan khusus sebagaimana yang dijelaskan pada buku Pedoman Umum Penyelenggaraan Pendidikan inklusif oleh direktorat PPK-LK Pendidikan Dasar Kementerian Pendidikan dan Kebudayaan tahun 2014. Kemudian, Pelaksanaan pembelajaran inklusif khususnya pada mata pelajaran Bahasa Arab di SD Pelita Bangsa GIS telah dilakukan dengan baik. Sekolah juga telah memberikan pembelajaran dengan kompetensi-kompetensi fungsional (skill) yang dibutuhkan untuk kemandirian dalam aktivitas kehidupan serta pembiasaan-pembiasaan spiritual untuk menumbuhkan sikap (akhlak), spiritualitas keagamaan serta perkembangan otak dan karakter siswa berkebutuhan khusus. Dan terakhir, SD Pelita Bangsa GIS telah melakukan penilaian dan pelaporan yang relevan dengan apa yang seharusnya dilakukan oleh sekolah penyelenggara program inklusif. Penilaian hasil belajar siswa berkebutuhandalam mata pelajaran Bahasa Arab dilakukan melalui penyesuaian terhadap KKM yang telah ditentukan. Hal unik yang dimiliki sekolah ini adalah memiliki instrumen peniliaian yang berbeda dengan sekolah pada umumnya dan disusun khusus oleh tim inklusif sekolah.

${ }^{34}$ Ms TE, Wali Kelas di SD Pelita Bangsa GIS, wawancara terstruktur pada hari Rabu, 29 April 2020 pukul 20.20 WIB melalui WhatsApp Voice Not

119 | Itsam Samrotul F. dan Esi Hairani: Implementasi Pembelajaran Insklusif,... 


\section{E. DAFTAR PUSTAKA}

Alfian. "Pendidikan Inklusif di Indonesia" dalam Jurnal Edu-Bio. Vol. 4 Tahun 2013.

Arifin, Zainal. Penelitian Pendidikan : Metode dan Paradigma Baru. Bandung: PT Remaja Rosdakaya. 2014

B. Uno, Hamzah. Perencanaan Pembelajaran. Jakarta: PT Bumi Aksara. 2012

Baharun, Hasan dan Robiatul Awwaliyah, "Pendidikan Inklusi Bagi Anak Berkebutuhan Khusus Dalam Perspektif Epistemologi Islam”, dalam jurnal MODELING. Jurnal Program Studi PGMI Volume 5. Nomor 1. Maret 2018

Departemen Pendidikan Nasional (Depdiknas). Tulkit LIRP-Merangkul Perbedaan: Perangkat untuk Pengembangan Inklusif Ramah terhadap Pembelajaran, Buku Khusus 3: Mengajar Anak-Anak dengan Disabilitas dalam Setting Inklusif. Jakarta: IDPN Indonesia. Arbeiter-Samariter-Bund. Handicap International. Plan Indonesia. 2009

Direktorat PPK-PLK, Buku Pedoman Penyelenggaraan Pendidikan Inklusif (sesuai Permendiknas no 70 tahun 2009), (Jakarta: Kementrian Pendidikan dan Kebudayaan, 2011), hlm.28

Direktorat PPK-LK Pendidikan Dasar, Pedoman Umum Penyelenggaraan Pendidikan Inklusif, (Jakarta: Kementrian Pendidikan dan Kebudayaan, 2011), hlm.3

Direktorat PPK-LK Pendidikan Dasar. Pedoman Umum Penyelenggaraan Pendidikan Inklusif. Jakarta: Kementrian Pendidikan dan Kebudayaan. 2011

Garnida, Dadang. Pengantar Pendidikan Inklusif. Bandung: PT Refika Aditama. 2018

Dwilestari, Ninin. Penelitian Kualitatif: Pendidikan Anak Usia Dini. Jakarta: PT RajaGrafindo Persada. 2013

Fathoni, Abdurahman. Metodologi Penelitian dan Teknik Pengumpulan Data. Jakarta: Rineka Cipta. 2006

Hamalik, Oemar. Perencanaan Pembelajaran Berdasarkan Sistem

Handayani, Titik dan Angga Sica Rahadian. "Peraturan Perundang-undangan dan Implementasi Pendidikan Inklusif” dalam Jurmal Masyarakat Indonesia. Volume 39, No. 1, Juni 2013

Hasbullah. Dasar-Dasar Ilmu Pendidikan. Jakarta: Raja Grafindo Persada. 2005

Husain Muslim, Al Imam Abi bin Al Hajja. Shahih Muslim. Kairo: Daar Ibnu Al Haitam. 2001.

Ihsan, Fuad. Dasar-Dasar Kependidikan. Jakarta: Rineka Cipta. 2013

Kustwawan, Dedy. Manajemen Pendidikan Inklusif. Jakarta: PT. Luxima Metro Media. 2016

Manzilati, Asfi. Metodologi Penelitian Kualitatif: Paradigma, Metode, dan Aplikasi. Malang: UB Press. 2017 
Margono. Metodologi Penelitian Pendidikan. Jakarta: PT Rineka Cipta. 2010

Martiyono. Perencanaan Pembelajaran Pendekatan Praktis Merencanakan Pembelajaran dan Pembelajaran Tematik Berdasarkan KTSP. Yogyakarta: Aswaja Pressindo. 2014

Nazir, Moh. Metode Penelitian

Nugroho, Agung dan Lia Mareza, "Model dan Strateg Pembelajaran Anak Berkebutuhan Khusus dalam Setting Pendidikan Inklusi", dalam jurnal Pendidikan DasarPerkhasa Volume 2, No.2. Oktober 2016,

Olivia, Stella. Pendidikan Inklusi untuk Anak-anak Berkebutuhan Khusus-Diintegrasikan Belajar di Sekolah Umum. Yogyakarta: CV Andi Ofset. 2017

Peraturan Pemerintah Republik Indonesia Nomor 19 Tahun 2005 tentang Standar Nasional Pendidikan

Pergub Banten Nomor 74 tahun 2014 tentang Pedoman Penyelenggaraan Pendidikan Inklusif di Provinsi Banten

Permendikbud Nomor 104 Tahun 2014 tentang Penilaian Hasil Belajar oleh Pendidik pada Pendidikan Dasar dan Menengah

Permendiknas Nomor 32 Tahun 2008 tentang standar Kualifikasi Akademik dan Kompetensi Guru Pendidikan Khusus

Permendiknas Nomor 70 Tahun 2009 tentang Pendidikan Inklusif bagi Peserta didik yang memiliki kelainan dan Memiliki Potensi Kecerdasan/Bakat Istimewa

PP No. 13 Tahun 2020 tentang Akomodasi yang Layak untuk Peserta Didik Penyandang Disabilitas

Praptiningrum, N. "Fenomena Penyelenggaraan Pendidikan Inklusif Bagi Anak Berkebutuhan Khusus" dalam Jurnal Pendidikan Khusus Vol. 17 No. 2 Nopember 2010, 33

Rahim, Abdul. "Pendidikan Inklusif Sebagai Strategi dalam Mewujudkan Pendidikan Untuk Semua”. dalam Jurnal Pendidikan Ke-SD-an. Vol. 3, Nomor 1. September 2016

Roza, Aslina dan Rifma. "Perencanaan Pembelajaran Anak Berkebutuhan Khusus Dalam Majamen Sekolah Inklusif'. dalam (JKPD) Jurnal Kajian Pendidikan Dasar Volume 5. Nomor 1 Januari 2020

Salamah,Umi. "Penjaminan Mutu Penilaian Pendidikan". dalam Jurnal Evaluasi. Vol.2. No. 1. Maret 2018

Setiadi, Hari. "Pelaksanaan Penilaian Pada Kurikulum 2013". dalam Jurnal Penelitian dan Evaluasi Pendidikan Volume 20. No 2. Desember 2016

SK Kepala Dinas Pendidikan dan Kebudayaan Kota Tangerang Selatan Nomor: 421/Kep.560-Bid.SD/2017 
Sudaryono. Metodologi Penelitian. Depok: PT Raja Grafindo Persada. 2018

Sugiyono. Cara Mudah Menyusun: Skripsi, Tesis, dan Disertasi. Bandung: Allfabet. 2013

Sukmadinata, Nana Syaodih. Metode Penelitian Pendidikan. Bandung: PT Remaja Rosdakarya. 2011

Sumadi, Suryabrata. Metodologi Penelitian Jakarta : PT Raja Grafindo Persad. 2000

Surat Edaran Dirjen Dikdasmen Depdiknas No. 380/C C6/MN/2003 tanggal 2 Januari 2003 Perihal Pendidikan Inklusif

Taufiq, Agus dkk. Pendidikan Anak di SD. Jakarta: Penerbit Universitas Terbua. 2011

Tim Pengembang MKDP Kurikulum dan Pembelajaran. Kurikulum dan Pembelajaran

Tiwiyanto, Teguh. Manajemen Kurikulum dan Pembelajaran. Jakarta: PT Bumi Aksara. 2015

Umami, Muzlikhatun. "Penilaian Autentik Pembelajaran Pendidikan Agama Islam dan Budi Pekerti dalam Kurikulum 2013”. dalam Jurnal Kependidikan Vol.6 No.2 November 2018

Undang-Undang Nomor 20 Tahun 2003

UU No. 20 Tahun 2003 tentang Sistem Pendidikan Nasional

UU No. 8 Tahun 2016 Tentang Penyandang Disabilitas

UU No. 23 Tahun 2002 tentang Perlindungan Anak

UUD 1945 (Amandemen) Pasal 31

Yusraini. "Kebijakan Pemerintah Terhadap Pendidikan Inklusif”. dalam jurnal Media Akademika. Vol. 28. No. 1. Januari 2016 